\title{
OPEN Archaeometric perspective on the emergence of brass north of the Alps around the turn of the Era
}

\author{
Daniel Bursák ${ }^{1 凶}$, Alžběta Danielisová ${ }^{1}$, Tomáš Magna $^{2}$, Petr Pajdla ${ }^{3}$, Jitka Míková2 \\ Zuzana Rodovská2, Ladislav Strnad ${ }^{4} \&$ Jakub Trubač ${ }^{4}$
}

Ancient brass (aurichalcum) was a valued commodity in the Antiquity, notably because of its gold-like appearance. After mastering brass fabrication using the cementation procedure in the first century $B C$ in the Mediterranean, this material became widely used by the Romans for coins, jewellery and other artefacts. Because of its visual qualities, it is believed that since this period, brass played an important role in diplomatic and economic contacts with indigenous communities, notably Celtic and Germanic tribes north of Danube and west of Rhine. To test this hypothesis, we performed for the first time the advanced statistical multivariate analysis based on chemical composition and lead isotope systematics, coupled with informed typo-chronological categorisation, of a suite of late Iron Age and Early Roman period (first century BC - first century AD) brass and other copper-alloy artefacts from the territory of Bohemia. In order to to discuss their provenance, the results were compared to known contemporary sources of material. The new results for brass artefacts from this early phase of the massive occurrence of Roman aurichalcum in the Barbarian territories point to the ore deposits in the western Mediterranean or the Massif Central area in Gaul, consistent with historical events. These new findings underscore the great economic and political importance of the new and rich mineral resources in the Transalpine Gaul acquired due to Caesar's military campaigns.

Brass is undoubtedly one of the most valued materials in Antiquity. Its high appreciation in the contemporaneous society is also underscored by the written sources, particularly in Pliny the Elder's and Cicero's works ${ }^{1,2}$. Since the discovery of $\mathrm{Zn}$-rich alloys in the material culture of the Early Roman period, several studies have summarised its origins, the technological process of its fabrication-including the cementation-by the Romans and its importance during that period ${ }^{3-7}$. It appears that the widespread distribution of brass is connected with the period of the reign of Augustus and his coinage reform in $23 \mathrm{BC}^{8}$.

The original brass produced by Roman workshops in the first half of the first century BC with very distinctive composition and material properties has been referred to as the aurichalcum ${ }^{1,4,7}$. Using modern analytical tools of chemical composition (XRF, EPMA, AAS, PIXE, ICP-MS), there has been some progress in identifying brass manufacture (possibly from the Roman imports) in the broader area of Europe among the artefacts dated already to the early $60 \mathrm{~s} \mathrm{BC}$; however, the geological provenance of used ores remained mostly unrevealed ${ }^{2,9-12}$. More recently, studies systematically dealing with the $\mathrm{Pb}$ isotope compositions of selected materials and artefacts frequently used in the society and for constructions, such as copper ${ }^{13-16}$, lead ${ }^{17,18}$, and brass ${ }^{2}$, have become available. It has been noted that the provenance analyses of ancient $\mathrm{Cu}$ from the Iron Age and later periods might be challenging due to the complexity of the interpretations imposed by numerous and often unknown resources, widespread material mixing, recycling, depletion, or other reasons. However, even if the determination of the exact origin of the artefacts in question proves to be difficult, the provenance studies remain to be a great source of information for the understanding of contemporary socio-economic networks that often are key to understanding the historical events ${ }^{18-21}$.

${ }^{1}$ Institute of Archaeology of the CAS Prague v.v.i., Letenská 4, 11801 Prague 1, Czech Republic. ${ }^{2}$ Czech Geological Survey, Klárov 3, 11821 Prague 1, Czech Republic. ${ }^{3}$ Department of Archaeology and Museology, Faculty of Arts, Masaryk University, Joštova 220/13, 66243 Brno, Czech Republic. ${ }^{4}$ Institute of Geochemistry, Mineralogy and Mineral Resources, Faculty of Science, Charles University, Albertov 6, 12843 Prague 2, Czech Republic. ${ }^{\boxplus}$ email: bursak@arup.cas.cz 
The historical framework of this study could be briefly outlined as a period starting with the decline of the late La Tène civilisation (conventionally linked with the Celts), around the middle of the first century BC, followed by a massive migration wave(s) of the early Germanic tribes (Marcomanni, Quadi, and others) sometime between the second half of the first century $\mathrm{BC}$ and the second century $\mathrm{AD}^{12,22}$. The beginning and the course of the Julio-Claudian dynasty with a distinct intensification of the Romano-'Barbarian' contacts is the primary time frame for the majority of samples presented in this study ${ }^{23-27}$. In this period, jewellery from the Germanic graves in Bohemia was identified to be made of high-quality brass, approaching the chemical composition of the original aurichalcum ${ }^{4,28,29}$. A possible Roman origin of the brass coming to indigenous territories was naturally assumed when these artefacts were originally investigated ${ }^{28}$. Especially in the case of early Germanic brooches of the so-called 'eye type' with ca. 20 wt.\% Zn, it was proposed that recycled Roman imports, primarily brass coins, were used for their fabrication ${ }^{29,30}$. The earliest brass artefacts in Bohemia are represented by a brass fourrée (counterfeit) stater from the oppidum of Stradonice ${ }^{31}$, brass Almgren 65 brooch from the oppidum of Závist, and several imported brass rings from the other oppida (Figs. 1, 2, Tables 2, 3, 4), all dated around the middle of the first century BC and, except for the coin, supposedly the products of Roman workshops imported to the North as exclusive jewellery pieces ${ }^{12}$. The striking richness and material diversity of copper-alloy artefacts in the Bohemian territory have frequently been related to the existence of the so-called Empire of Marobudus, a power structure that kept friendly relations with the expanding Roman Empire after the critical defeat of three legions in the Battle of the Teutoburg Forest in $\mathrm{AD} 9^{27,32}$. In that period, the Central European territory was at the intersection of the territorial interests of the expanding Roman Empire, new migration waves of the Germanic tribes from the North and the West, and the remainder of the late Celtic population. As such, this territory interconnected many cultural traditions manifested in the material culture. Those were, in particular, the costume parts (brooches, belts, pins and other personal artefacts), imported luxury items such as bronze drinking vessels, tableware, and other artefacts.

All these observations make Bohemia an exceptionally well-suited territory for studying brass production and circulation patterns compared to other 'Barbarian' territories north of the Alps and east of the Rhine River (Fig. 1). However, there still is a limited knowledge on the nature of trade with brass between the Romans and the indigenous populations (i.e. Celtic and Germanic tribes) beyond the Roman territories. The only known indication from the region north of the Alps is a hoard retrieved from the Rhine River, containing over 50 bars, some of them made of brass ${ }^{30}$. The massive emergence of brass artefacts north of the Alps and in Bohemia in particular, almost unknown during the preceding La Tène period, corresponds well with a significant influx of Roman imports to the Barbarian territories in the Early Roman period, i.e. between the second half of the first century $\mathrm{BC}$ and the first half of the first century $\mathrm{AD}^{28,29,32-34}$. Here, we present new compositional and $\mathrm{Pb}$ isotope data for the early Roman brass artefacts from the territory of Bohemia to initiate the discussion on the currently scarce archaeometric research on the emergence of early brass in Europe. The character of bronze and brass from the Early Roman period is compared with the chronologically preceding finds from the Late Iron Age ${ }^{20,21,35}$.

\section{Material}

Artefacts studied and sampling design. In total, 50 Late Iron Age and Early Roman period artefacts from the territory of Bohemia were sampled for compositional and $\mathrm{Pb}$ isotopic analyses (Figs. 1, 2). Most items come from metal detector prospections and the information about their original context is thus uncertain. Nonetheless, all samples can be characterised in terms of localisation, typological determination, cultural provenance and archaeological dating (Tables 1,2). The selection of samples for further investigations was driven by identifying those artefacts among the cultural groups most likely fabricated from brass.

Categorisation of samples. A rich typological diversity of the finds led to a robust scholarly tradition in the past, which was aimed to results in a thorough typo-chronological evaluation with a great effort put into the detailed mapping, sequencing and cataloguing of the finds ${ }^{36-46}$. A vital research premise was to establish the general typo-chronological groups of personal jewellery and other artefacts, usually described as the 'Western tradition' (i.e. Gallic and Rhenish), the 'Danube tradition' (or Norico-Pannonian, Rhaetian), or in a more general sense the 'Roman-provincial tradition'. Such categorisation represents a valuable methodological tool for working with archaeometric data because it can be used as independent evidence.

The following cultural and chronological groups of brass artefacts from this study were defined for the correlation with the chemical analysis:

La Tène ('LT-Brass'): artefacts made in the late La Tène tradition of metallurgical production, usually carried out at the oppida or other major agglomerations (mainly in the Middle Danube area). Their chronological assessment and interpretation are based on a recent study of the late Iron Age in Bohemia ${ }^{12}$. This group contains four brass artefacts: a late Almgren 65 type brooch and three imported brass rings of the Roman provenance (Fig. 2, Table 2).

Local ('L'): artefacts generally supposed to be fabricated in the early 'Barbarian' metallurgical tradition. This material culture commonly is associated with the Germanic tribes appearing in the Bohemian territory from the second half of the first century BC. This group mostly contains personal artefacts, especially eye brooches of the Almgren 45-49 type t7,47,48. $^{3}$.

Import ('I'): finds not of the 'Barbarian' provenance; they usually are considered to be the diplomatic gifts brought to the Bohemian territory by trade, exchange or as booty from the territories controlled by the Romans $^{32,49-51}$. Because several different typological groups are included in this broad category, further subdivisions were needed, such as 'Noric' and 'Western'. Also, more ambivalent types in terms of the place of origin were included, such as Almgren 18 brooches, which sometimes are interpreted as being produced locally. 

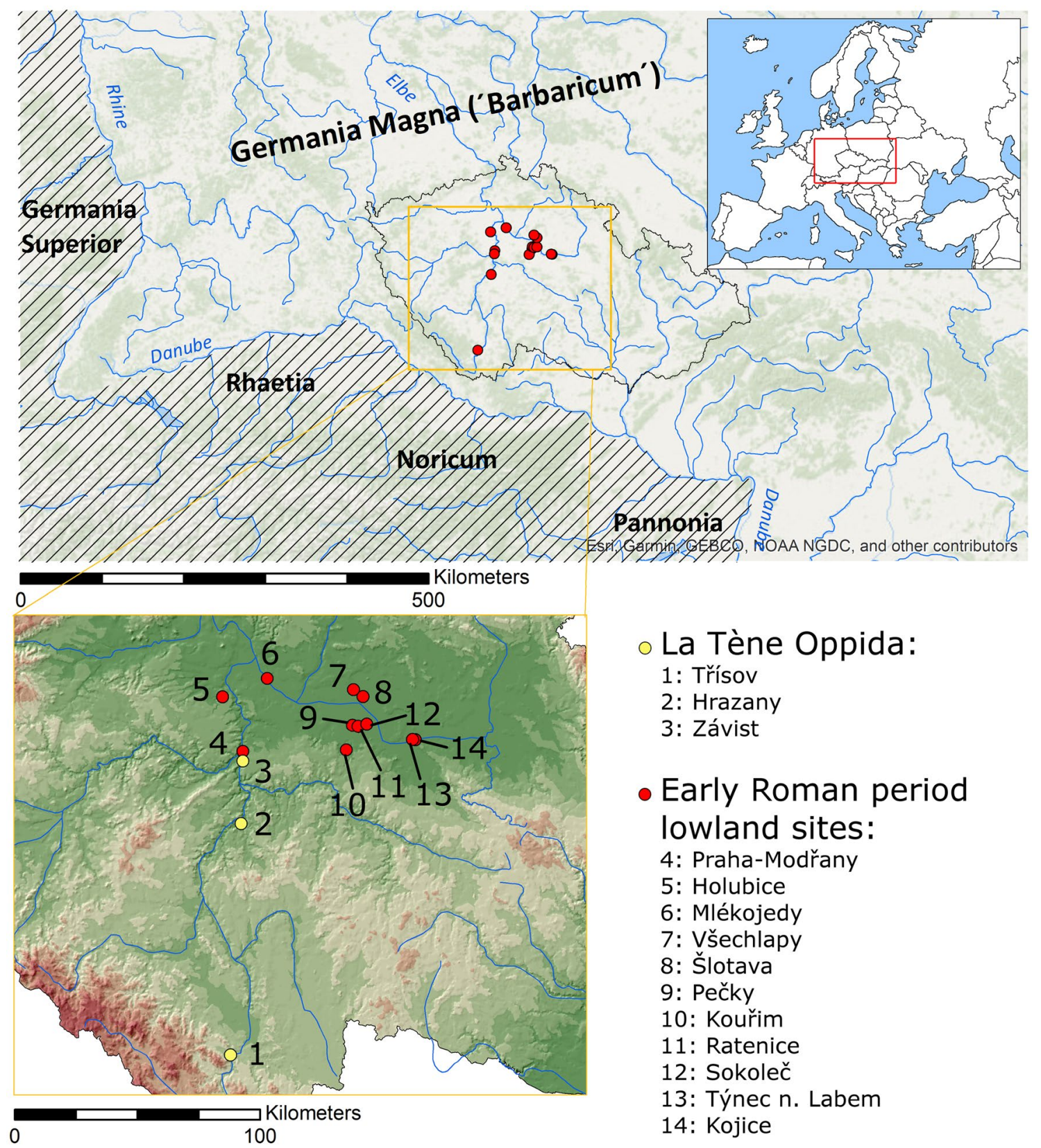

- La Tène Oppida:

\section{1: Tř́sov \\ 2: Hrazany \\ 3: Závist}

- Early Roman period lowland sites:
4: Praha-Modřany
5: Holubice
6: Mlékojedy
7: Všechlapy
8: Šlotava
9: Pečky
10: Kouřim
11: Ratenice
12: Sokoleč
13: Týnec n. Labem
14: Kojice

Figure 1 (. A) Geographical overview of Central Europe with main territorial units of the later Roman provinces (hatched areas) at the beginning of the first cent. AD; (B) a detailed area of interest in Bohemia with sites providing samples for this study. Background topographic map of Europe (A) () Esri, HERE, Garmin, Intermap, increment P Corp., GEBCO, USGS, FAO, NPS, NRCAN, GeoBase, IGN, Kadaster NL, Ordnance Survey, Esri Japan, METI, Esri China (Hong Kong), (C) OpenStreetMap contributors, and the GIS User Community; digital elevation model of the terrain in the (B) @ C ĆUZK, https://ags.cuzk.cz/geoprohlizec/ [ags. cuzk.cz]. Made in ArcGis software, ver.10.2.2 for Desktop (www.esri.com \esri.com]).

Bohemian finds appear to be exogenous and ultimately connected with the populations that occupied the territory from the second half of the first century $\mathrm{BC}^{52}$.

Noric ('N'): artefacts made in the cultural tradition of the territories around the Middle Danube zone and the Eastern Alps, including the parts of the so-called 'Norico-Pannonian costume' and finds mainly occurring in the territory of ancient Rhaetia (roughly the Alpine zone of today's Austria). Brooches and other jewellery are thought to represent the continuity from the preceding late La Tène costume tradition ${ }^{36,40,43,53}$.

Western ('W'): this category has been used as a label for Alesia, Almgren 19 (including its subvariants), Almgren 15, and the so-called Gallic brooches of the types Feugère 13b, 19b and 19d. These artefacts mainly occurred around the Middle Rhine area or in eastern Gaul territory. To avoid ambiguity in cultural determination, some types, such as the Aucissa and Almgren 18, were categorised simply as Import ('I'), indicating their non-Germanic provenance. 
www.nature.com/scientificreports/

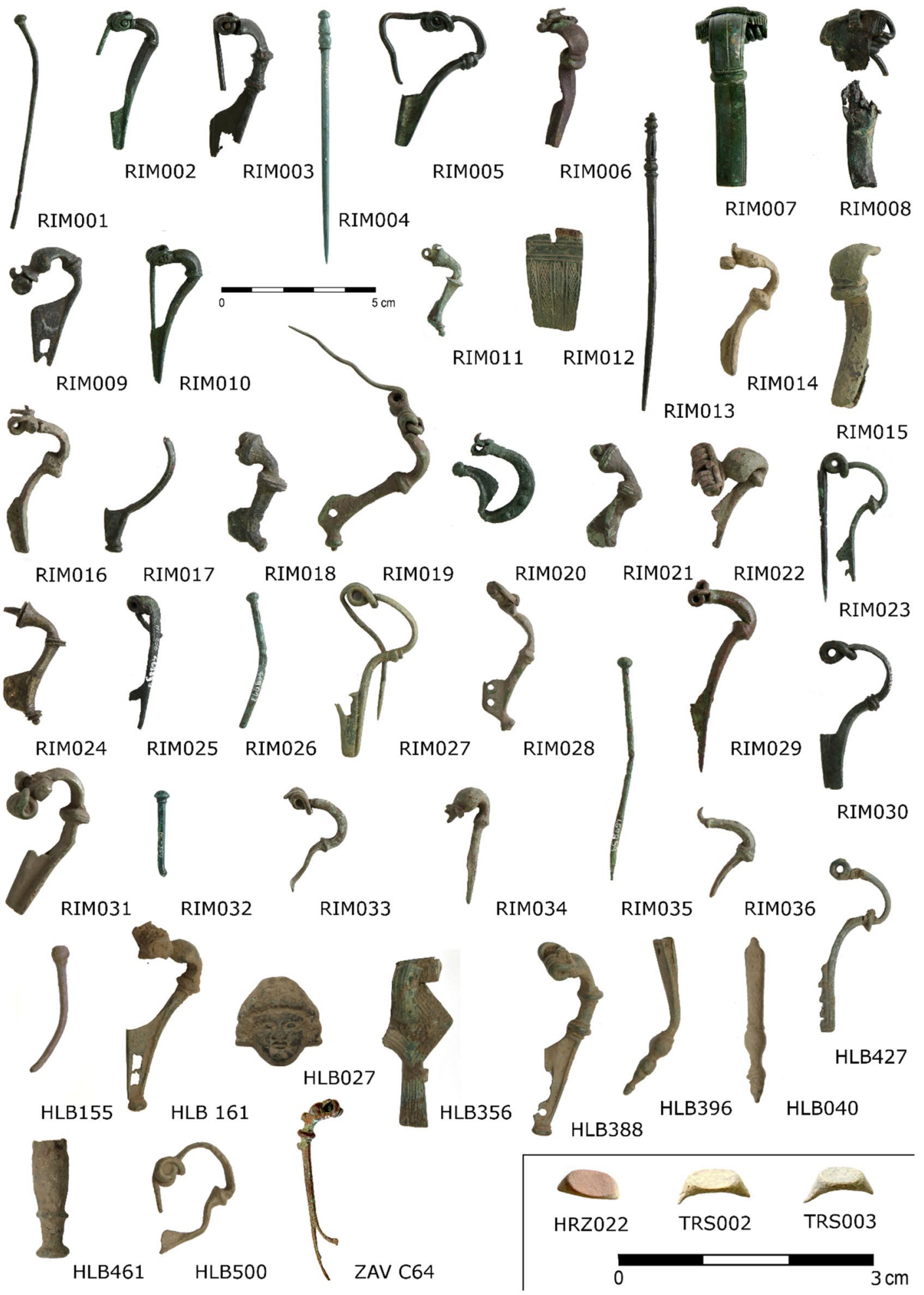

Figure 2. Analysed artefacts with captions corresponding to the sample description in the Tables 2, 3, 4. For further information on displayed artefacts see Suppl. Table 1.

Results

Chemical composition. Chemical composition of the analysed samples is summarized in Table 3. For the comparison with data published elsewhere, all compositional data used in this work are presented in the form of the analytical totals normalised to $100 \mathrm{wt} . \%$.

Majority of analysed samples is represented by $\mathrm{Cu}$ or $\mathrm{Cu}$-based alloys with high $\mathrm{Zn}$ contents (Suppl. Figure 2). The visible divide within the group of brass artefacts occurs at $15 \mathrm{wt} . \% \mathrm{Zn}$ (Suppl. Figure ea). Seventeen of the 50 samples in Table 3 belong to J. Riederer's category of Roman brass with very high Zn content (above $20 \mathrm{wt.} \%{ }^{56}$ )

Scientific Reports |

(2022) 12:374 |

https://doi.org/10.1038/s41598-021-04044-7

nature portfolio 


\begin{tabular}{|c|c|c|c|c|c|}
\hline & \multicolumn{2}{|c|}{ La Tène period } & \multirow{2}{*}{\multicolumn{3}{|c|}{\begin{tabular}{|l|} 
Early roman period \\
-
\end{tabular}}} \\
\hline $130 / 120-70$ s BC & \multirow{2}{*}{ LT } & LT D1a & \multirow{2}{*}{\multicolumn{3}{|c|}{\begin{tabular}{|l}
- \\
- \\
\end{tabular}}} \\
\hline $70 \mathrm{~s}-50 / 40 \mathrm{~s} \mathrm{BC}$ & & LT D1b & & & \\
\hline from $60 \mathrm{~s} / 40 \mathrm{~s}-20 \mathrm{~s} / 0 \mathrm{BC}$ & \multicolumn{5}{|c|}{ LT D2 / R A } \\
\hline $10 / 5$ BC-AD 20/30 & \multicolumn{2}{|l|}{-} & \multirow{3}{*}{ R B } & \multirow{2}{*}{ R B1 } & R B1a \\
\hline AD $20 / 30-40 / 50$ & - & & & & R Blb \\
\hline AD 50/70-150/160 & \multicolumn{2}{|l|}{-} & & \multicolumn{2}{|l|}{ R B2 } \\
\hline
\end{tabular}

Table 1. Summary of the chronological system employed in the sample categorisation. The generally accepted chronological framework for the late La Tène $\mathrm{e}^{12}$ and the Early Roman period ${ }^{22,44,54,55}$, respectively, were followed.

and the absence of $\mathrm{Pb}$ and $\mathrm{Sn}$. However, four of these samples also contained $>1 \mathrm{wt} . \% \mathrm{Sn}$. It is worth mentioning that such an elevated $\mathrm{Sn}$ content in otherwise "pure" $\mathrm{Cu}-\mathrm{Zn}$ alloys is present in samples from the late Iron Age and marks a recognisable difference from the later Roman $\mathrm{Cu}-\mathrm{Zn}$ alloy. Ten samples belong to Riederer's category of Roman brass with high $\mathrm{Zn}$ content (10-20 wt. \% ${ }^{56}$ ); 9 samples represent the category of Roman $\mathrm{Sn}$ -brass with high Zn content (Zn 10-20 wt. \%, Sn 1-10 wt. \% ${ }^{56}$ ). Samples with Zn content below approx. 16 wt. \% tend to have slightly increased Sn content, up to $2.1 \mathrm{wt}$. \%. Four samples were detected to be made of Sn bronze without the addition of $\mathrm{Zn}$. All belong to the 'L' category, while only two of them are Sn-rich bronzes ( $\mathrm{Sn}>10$ wt.\%.). Generally, variations in main alloying components-Pb, $\mathrm{Zn}$ and $\mathrm{Sn}-$ (Fig. 3) are most likely compatible with different chronology. Very high $\mathrm{Zn}$ contents (median at 17 wt.\%) on the one hand and very low $\mathrm{Sn}$ and $\mathrm{Pb}$ concentrations on the other are typical for the phase R B1 (10 BC-AD 50). There is a slight tendency towards more consistent and higher $\mathrm{Zn}$ contents among samples towards the end of this phase (ca. AD 30-50).

Brass with significantly lower Zn contents (2-9 wt. \%) was detected in categories of imports ('I') from the beginning of the Early Roman period (second half of the first century BC). These artefacts also have similiar contents of Zn and Sn. The second category with a similar position in the composition plot (Fig. 3; Suppl. Figure 1) is partly represented by samples of the local ('L') origin that usually are dated around the middle of the first century AD (phase R B2). There are also two leaded Cu alloys: (i) a drinking horn fitting, and (ii) a fragment of a handle of the Roman imported vessel (bronze decoration with a human mask). A single case of a brooch (sample RIM008) with an exceptionally high Ag content of 20.8 wt. \% was also observed.

Principal component analysis (PCA) was performed for a more detailed statistical evaluation of the chemical composition of samples from this study. The choice of minor/trace elements $(\mathrm{Pb}, \mathrm{Co}, \mathrm{Sb}, \mathrm{Ag})$ has been made considering their symptomatic value for provenance studies ${ }^{57,58}$. The resulting factor scores are plotted in Fig. 4. The most extensive dispersion is observed in the category of local items ('L'), followed by the imported items ('I'), reflecting significant variations in the general composition of the used alloys (Fig. 3). Most samples in the 'N' category tend to have higher Ag contents (0.26 - $1.2 \mathrm{wt}$. \%) which may show consistency with their supposed Alpine origin (see below). A slightly negative correlation between Co and Ag was observed; however, there does not appear to be a clear correlation with the typo-chronological categorisation of samples (Fig. 4).

Lead isotope systematics. Lead isotope analysis shows similar results as the PCA (Fig. 5). The most significant variability is observed in the category of local items ('L'), followed by a slightly more homogeneous Norican ('N') group and the imports ('I'). Samples in the 'Western' category ('W') form the tightest cluster, which is also coherent chronologically (phase R B1; Fig. 5a). Their linear trend and its spatial overlap are most similar with the $\mathrm{Pb}$ isotope systematics of the ores from the Massif Central (Fig. 6). Almost all samples from the 'LT-brass' category are mutually close and show a significant consistency with the ore deposits in the western Mediterranean (i.e. Iberia) and the Massif Central in France. Sample TRS 003 is offset from the rest of the suite but still plots in the $\mathrm{Pb}$ isotope space of the Spanish or French deposits.

All brass artefacts in the 'I' category (imports) are from the phase R A, and all of these samples show a tendency towards more radiogenic ${ }^{206} \mathrm{~Pb} /{ }^{204} \mathrm{~Pb}$ ratios. A tendency towards less radiogenic ${ }^{207} \mathrm{~Pb} /{ }^{204} \mathrm{~Pb}$ and ${ }^{206} \mathrm{~Pb} /{ }^{204} \mathrm{~Pb}$ ratios is observed for items from the chronologically youngest period (R B2). A costume pin sample RIM 001 made of brass with high $\mathrm{Zn}$ content $(>15 \mathrm{wt} . \%)$ represents an 'outlier' with the lowest ${ }^{207} \mathrm{~Pb} /{ }^{204} \mathrm{~Pb}$. A clear tendency of samples with low Zn content $(<5 \mathrm{wt} . \%)$, dated either in the earliest or in the latest phase (R A or R B2), towards less radiogenic ${ }^{207} \mathrm{~Pb} /{ }^{204} \mathrm{~Pb}$ values is apparent (Fig. 5b). The samples from the phase $\mathrm{R} \mathrm{B1}$ with high $\mathrm{Zn}$ contents appear to be dispersed around ${ }^{206} \mathrm{~Pb} /{ }^{204} \mathrm{~Pb}$ value of 15.68 and are relatively homogeneous. Lead-rich $(\sim 5$ wt.\%) imported vessel has the same $\mathrm{Pb}$ isotope systematics as the high- $\mathrm{Zn}$ low-Pb items from the phase R B1. A drinking horn fitting with the highest $\mathrm{Pb}$ content of 9.5 wt. \% plots separately with ${ }^{207} \mathrm{~Pb} /{ }^{204} \mathrm{~Pb}$ and ${ }^{206} \mathrm{~Pb} /{ }^{204} \mathrm{~Pb}$ ratios of 18.55 and 15.65 , respectively.

\section{Discussion}

The original aurichalcum, i.e. the brass produced in Rome, must have contained at least $22-28$ wt. $\% \mathrm{Zn}^{4}$. However, the content of $\mathrm{Zn}$ in aurichalcum started to decrease already in the first century AD and later produced aurichalcum further continued to lose its original qualities ${ }^{62}$. It was shown that alloy with the $\mathrm{Zn}$ content between 10 and $15 \mathrm{wt} . \%$, that could be produced via a simple dilution process of equal quantities of bronze and the aurichalcum, already yielded its typical golden colour that was in demand among the indigenous communities ${ }^{1,4,63}$. 


\begin{tabular}{|c|c|c|c|c|c|}
\hline Lab. No & Site & GPS & Typology & Category & Dating \\
\hline RIM012 & Kouřim & $50.0061456 \mathrm{~N}, 14.9959014 \mathrm{E}$ & Alesia & I & A \\
\hline RIM017 & Mlékojedy & $50.2666303 \mathrm{~N}, 14.5442911 \mathrm{E}$ & Aucissa & I & A-B1 \\
\hline RIM020 & Všechlapy & $50.2261361 \mathrm{~N}, 15.0351342 \mathrm{E}$ & Hinge-pin brooch & I & B \\
\hline HLB027 & Holubice & $50.1982678 \mathrm{~N}, 14.2899803 \mathrm{E}$ & Imported vessel & I & B \\
\hline RIM005 & Všechlapy & $50.2261361 \mathrm{~N}, 15.0351342 \mathrm{E}$ & A $18 \_K \mathrm{Na}$ & I & A-B1 \\
\hline RIM030 & Mlékojedy & $50.2666303 \mathrm{~N}, 14.5442911 \mathrm{E}$ & A 18 & I & A-B1 \\
\hline RIM006 & Týnec n. Labem & $50.0439286 \mathrm{~N}, 15.3705692 \mathrm{E}$ & A 45 & $\mathrm{~L}$ & B1b \\
\hline RIM008 & Pečky & $50.0962303 \mathrm{~N}, 15.0297508 \mathrm{E}$ & A 24 & $\mathrm{~L}$ & B1a \\
\hline RIM011 & Šlotava & $50.2007908 \mathrm{~N}, 15.0897411 \mathrm{E}$ & Trumpet style brooch & $\mathrm{L}$ & B1c-B2a \\
\hline RIM014 & Mlékojedy & $50.2666303 \mathrm{~N}, 14.5442911 \mathrm{E}$ & needle (costume) & $\mathrm{L}$ & B \\
\hline RIM015 & Kojice & $50.0423619 \mathrm{~N}, 15.3877225 \mathrm{E}$ & A 45 & $\mathrm{~L}$ & B1b \\
\hline RIM016 & Šlotava & $50.2007908 \mathrm{~N}, 15.0897411 \mathrm{E}$ & A 45b & $\mathrm{L}$ & B1b \\
\hline RIM018 & Sokoleč & $50.1003031 \mathrm{~N}, 15.1126050 \mathrm{E}$ & Trumpet style brooch with Ag decoration & $\mathrm{L}$ & B2a \\
\hline RIM021 & Šlotava & $50.2007908 \mathrm{~N}, 15.0897411 \mathrm{E}$ & Trumpet style brooch & $\mathrm{L}$ & B2a \\
\hline RIM023 & Mlékojedy & $50.2666303 \mathrm{~N}, 14.5442911 \mathrm{E}$ & A $2 \mathrm{a}$ & $\mathrm{L}$ & Bla \\
\hline RIM024 & Sokoleč & $50.1003031 \mathrm{~N}, 15.1126050 \mathrm{E}$ & Trumpet style brooch & $\mathrm{L}$ & B1b-B2 \\
\hline RIM025 & Mlékojedy & $50.2666303 \mathrm{~N}, 14.5442911 \mathrm{E}$ & Spoon brooch & $\mathrm{L}$ & LT D1b-D2 \\
\hline RIM026 & Mlekojedy & $50.2666303 \mathrm{~N}, 14.5442911 \mathrm{E}$ & needle (costume) & $\mathrm{L}$ & B \\
\hline RIM027 & Kojice & $50.0423619 \mathrm{~N}, 15.3877225 \mathrm{E}$ & A 2a & $\mathrm{L}$ & B1a \\
\hline RIM031 & Ratenice & $50.0920564 \mathrm{~N}, 15.0620225 \mathrm{E}$ & A 45b & $\mathrm{L}$ & B1b \\
\hline HLB040 & Holubice & $50.1982678 \mathrm{~N}, 14.2899803 \mathrm{E}$ & Belt fitting & $\mathrm{L}$ & B1 \\
\hline HLB155 & Holubice & $50.1982678 \mathrm{~N}, 14.2899803 \mathrm{E}$ & needle (costume) & $\mathrm{L}$ & B \\
\hline HLB396 & Holubice & $50.1982678 \mathrm{~N}, 14.2899803 \mathrm{E}$ & Belt fitting & $\mathrm{L}$ & B \\
\hline HLB427 & Holubice & $50.1982678 \mathrm{~N}, 14.2899803 \mathrm{E}$ & A 2a & $\mathrm{L}$ & B1a \\
\hline HLB461 & Holubice & $50.1982678 \mathrm{~N}, 14.2899803 \mathrm{E}$ & Drinking horn fitting & $\mathrm{L}$ & B \\
\hline HLB500 & Holubice & $50.1982678 \mathrm{~N}, 14.2899803 \mathrm{E}$ & A 2a & $\mathrm{L}$ & B1a \\
\hline RIM001 & Mlékojedy & $50.2666303 \mathrm{~N}, 14.5442911 \mathrm{E}$ & needle (costume) & $\mathrm{L}$ & B \\
\hline RIM004 & Mlékojedy & $50.2666303 \mathrm{~N}, 14.5442911 \mathrm{E}$ & needle (costume) & $\mathrm{L}$ & B1 \\
\hline RIM007 & Praha-Modřany & $49.9991067 \mathrm{~N}, 14.4076225 \mathrm{E}$ & A 24 & $\mathrm{~L}$ & B1a \\
\hline RIM013 & Kojice & $50.0423619 \mathrm{~N}, 15.3877225 \mathrm{E}$ & A 49? & $\mathrm{L}$ & B1b \\
\hline RIM032 & Mlékojedy & $50.2666303 \mathrm{~N}, 14.5442911 \mathrm{E}$ & needle (costume) & $\mathrm{L}$ & B1 \\
\hline RIM033 & Šlotava & $50.2007908 \mathrm{~N}, 15.0897411 \mathrm{E}$ & A 2 & $\mathrm{~L}$ & B1a \\
\hline RIM035 & Mlékojedy & $50.2666303 \mathrm{~N}, 14.5442911 \mathrm{E}$ & needle (costume) & $\mathrm{L}$ & B1 \\
\hline HRZ022 & Hrazany & $49.7343239 \mathrm{~N}, 14.4015322 \mathrm{E}$ & Ring & LT-Brass & LT D \\
\hline TRS 002 & Trísov & $48.8869861 \mathrm{~N}, 14.3518881 \mathrm{E}$ & Ring & LT-Brass & LT D \\
\hline TRS 003 & Trísov & $48.8869861 \mathrm{~N}, 14.3518881 \mathrm{E}$ & Ring & LT-Brass & LT D \\
\hline ZAV C64 & Závist & $49.9631869 \mathrm{~N}, 14.4087258 \mathrm{E}$ & A 65 & LT-Brass & LT D1b \\
\hline RIM009 & Šlotava & $50.2007908 \mathrm{~N}, 15.0897411 \mathrm{E}$ & A 67a & $\mathrm{N}$ & B1a \\
\hline HLB161 & Holubice & $50.1982678 \mathrm{~N}, 14.2899803 \mathrm{E}$ & A $67-67 / 68$ & $\mathrm{~N}$ & B1b \\
\hline HLB388 & Holubice & $50.1982678 \mathrm{~N}, 14.2899803 \mathrm{E}$ & A 236a & $\mathrm{N}$ & B1a \\
\hline RIM003 & Týnec n. Labem & $50.0439286 \mathrm{~N}, 15.3705692 \mathrm{E}$ & A 236 & $\mathrm{~N}$ & B1 \\
\hline RIM019 & Ratenice & $50.0920564 \mathrm{~N}, 15.0620225 \mathrm{E}$ & A 68 & $\mathrm{~N}$ & B1b-B2a \\
\hline RIM022 & Šlotava & $50.2007908 \mathrm{~N}, 15.0897411 \mathrm{E}$ & A 67 & $\mathrm{~N}$ & B1 \\
\hline RIM028 & Ratenice & $50.0920564 \mathrm{~N}, 15.0620225 \mathrm{E}$ & A $68 ?$ & $\mathrm{~N}$ & B1b-B2a \\
\hline RIM034 & Šlotava & $50.2007908 \mathrm{~N}, 15.0897411 \mathrm{E}$ & A 67 & $\mathrm{~N}$ & B1 \\
\hline RIM002 & Praha-Modřany & $49.9991067 \mathrm{~N}, 14.4076225 \mathrm{E}$ & A 19aI & $\mathrm{W}$ & B1a \\
\hline RIM029 & Týnec n. Labem & $50.0439286 \mathrm{~N}, 15.3705692 \mathrm{E}$ & A 19 & $\mathrm{~W}$ & B1 \\
\hline HLB356 & Holubice & $50.1982678 \mathrm{~N}, 14.2899803 \mathrm{E}$ & Feugère 19d & W & B1 \\
\hline RIM010 & Praha-Modřany & $49.9991067 \mathrm{~N}, 14.4076225 \mathrm{E}$ & A 19aI & $\mathrm{W}$ & B1a \\
\hline RIM036 & Šlotava & $50.2007908 \mathrm{~N}, 15.0897411 \mathrm{E}$ & A 19 & W & B1 \\
\hline
\end{tabular}

Table 2. Description of analysed samples with their localisation, category of cultural provenance (see chapter 2.2 and Table 1), and dating. Brooches in the typological system of O. Almgren ${ }^{94}$ were abbreviated as A $(X)$. 


\begin{tabular}{|c|c|c|c|c|c|c|c|c|c|c|c|c|c|c|c|c|c|}
\hline Lab. No & $\mathrm{Cu}$ & $\mathrm{Fe}$ & Co & $\mathrm{Ni}$ & Zn & As & $\mathrm{Ag}$ & Sn & Sb & $\mathrm{Pb}$ & $\mathrm{Au}$ & $\mathrm{Cr}$ & Mn & Pd & Mo & Ga & SUM wt.\% \\
\hline RIM012 & 85.1 & bdl & 0.008 & bdl & 18.34 & bdl & 1.129 & 0.17 & 0.171 & 2.868 & 0.017 & bdl & bdl & 0.014 & 0.003 & 0.000 & 100 \\
\hline RIM017 & 80.4 & bdl & 0.003 & 0.014 & 22.39 & bdl & 1.308 & 0.05 & 0.211 & 0.424 & 0.010 & bdl & bdl & 0.010 & 0.002 & 0.001 & 100 \\
\hline RIM020 & 80.3 & bdl & 0.002 & bdl & 1.73 & bdl & 0.437 & 6.56 & 0.010 & 0.216 & 0.041 & bdl & bdl & 0.010 & 0.002 & 0.001 & 100 \\
\hline HLB027 & \begin{tabular}{|l|}
94.8 \\
\end{tabular} & 0.140 & 0.001 & 0.004 & 14.17 & bdl & 0.002 & 1.80 & 0.000 & 5.049 & 0.010 & bdl & bdl & 0.001 & 0.000 & bdl & 100 \\
\hline RIM005 & 88.1 & 0.000 & 0.002 & 0.071 & 3.21 & bdl & 0.634 & 4.10 & 0.206 & 0.879 & 0.003 & bdl & bdl & 0.000 & 0.000 & bdl & 100 \\
\hline RIM030 & 84.5 & 0.120 & 0.002 & 0.039 & 5.22 & bdl & 0.542 & 5.43 & 0.127 & 0.883 & 0.001 & bdl & bdl & 0.000 & 0.000 & 0.001 & 100 \\
\hline RIM006 & 76.8 & bdl & 0.001 & bdl & 16.56 & bdl & 0.470 & 1.17 & 0.059 & 0.182 & 0.023 & bdl & bdl & 0.003 & 0.000 & 0.001 & 100 \\
\hline RIM008 & 70.2 & bdl & 0.003 & 0.218 & 19.92 & bdl & 20.835 & 0.10 & 0.213 & 0.136 & 0.057 & bdl & bdl & 0.012 & 0.003 & 0.001 & 100 \\
\hline RIM011 & 90.5 & bdl & 0.005 & bdl & 20.17 & bdl & 1.192 & 0.01 & 0.090 & 0.891 & 0.019 & bdl & bdl & 0.015 & 0.004 & bdl & 100 \\
\hline RIM014 & 81.1 & bdl & 0.002 & bdl & 15.52 & bdl & 0.791 & 2.15 & 0.010 & 0.336 & 0.007 & bdl & bdl & \begin{tabular}{|l|}
0.007 \\
\end{tabular} & \begin{tabular}{|l|}
0.001 \\
\end{tabular} & 0.001 & 100 \\
\hline RIM015 & \begin{tabular}{|l|}
78.2 \\
\end{tabular} & bdl & \begin{tabular}{|l|}
0.002 \\
\end{tabular} & bdl & 3.83 & bdl & 1.370 & 3.61 & 0.129 & 0.255 & 0.010 & bdl & bdl & 0.009 & \begin{tabular}{|l|}
0.002 \\
\end{tabular} & bdl & 100 \\
\hline RIM016 & \begin{tabular}{|l|}
79.3 \\
\end{tabular} & bdl & 0.001 & bdl & \begin{tabular}{|l|}
18.78 \\
\end{tabular} & bdl & 0.295 & 0.23 & 0.007 & 0.167 & 0.007 & bdl & bdl & 0.007 & 0.001 & 0.001 & 100 \\
\hline RIM018 & 91.0 & bdl & 0.003 & bdl & 15.01 & bdl & 1.003 & 1.33 & 0.079 & 0.386 & 0.028 & bdl & bdl & 0.008 & 0.001 & bdl & 100 \\
\hline RIM021 & 81.9 & bdl & \begin{tabular}{|l|}
0.004 \\
\end{tabular} & bdl & \begin{tabular}{|l|}
19.14 \\
\end{tabular} & bdl & 1.438 & 0.48 & 0.083 & 0.215 & 0.025 & bdl & bdl & \begin{tabular}{|l|}
0.012 \\
\end{tabular} & \begin{tabular}{|l|}
0.002 \\
\end{tabular} & bdl & 100 \\
\hline RIM023 & \begin{tabular}{|l|}
79.4 \\
\end{tabular} & bdl & \begin{tabular}{|l|}
0.005 \\
\end{tabular} & bdl & 8.88 & bdl & 0.600 & 5.32 & 0.018 & 0.353 & 0.021 & bdl & bdl & 0.011 & 0.002 & bdl & 100 \\
\hline RIM024 & \begin{tabular}{|l|}
84.2 \\
\end{tabular} & bdl & 0.003 & bdl & \begin{tabular}{|l|}
18.03 \\
\end{tabular} & bdl & 0.957 & 0.34 & 0.177 & 0.445 & 0.016 & bdl & bdl & 0.009 & \begin{tabular}{|l|}
0.002 \\
\end{tabular} & bdl & 100 \\
\hline RIM025 & 79.6 & bdl & \begin{tabular}{|l|}
0.002 \\
\end{tabular} & bdl & bdl & bdl & 0.876 & 10.11 & 0.007 & 1.144 & 0.011 & bdl & bdl & 0.006 & \begin{tabular}{|l|l|}
0.001 \\
\end{tabular} & bdl & 100 \\
\hline RIM026 & 88.4 & bdl & \begin{tabular}{|l|}
0.006 \\
\end{tabular} & bdl & bdl & bdl & 1.041 & 13.45 & 0.108 & 0.321 & 0.015 & bdl & bdl & \begin{tabular}{|l|}
0.008 \\
\end{tabular} & \begin{tabular}{|l|}
0.001 \\
\end{tabular} & bdl & 100 \\
\hline RIM027 & 85.6 & bdl & \begin{tabular}{|l|}
0.001 \\
\end{tabular} & \begin{tabular}{|l|}
0.015 \\
\end{tabular} & 20.06 & bdl & 0.643 & 0.03 & 0.297 & 0.014 & 0.013 & bdl & bdl & 0.003 & \begin{tabular}{|l|}
0.000 \\
\end{tabular} & bdl & 100 \\
\hline RIM031 & \begin{tabular}{|l|}
77.9 \\
\end{tabular} & bdl & 0.002 & bdl & 20.12 & bdl & 0.786 & 0.60 & 0.059 & 0.470 & 0.010 & bdl & bdl & \begin{tabular}{|l|}
0.007 \\
\end{tabular} & \begin{tabular}{|l|}
0.001 \\
\end{tabular} & bdl & 100 \\
\hline HLB040 & 85.1 & \begin{tabular}{|l|}
0.890 \\
\end{tabular} & \begin{tabular}{|l|}
0.004 \\
\end{tabular} & \begin{tabular}{|l|}
0.003 \\
\end{tabular} & \begin{tabular}{|l|}
0.01 \\
\end{tabular} & bdl & 0.004 & 0.03 & 0.043 & 0.189 & 0.014 & bdl & bdl & \begin{tabular}{|l|}
0.001 \\
\end{tabular} & \begin{tabular}{|l|}
0.001 \\
\end{tabular} & \begin{tabular}{|l|}
0.001 \\
\end{tabular} & 100 \\
\hline HLB155 & 81.9 & \begin{tabular}{|l|l|}
0.350 \\
\end{tabular} & \begin{tabular}{|l|}
0.000 \\
\end{tabular} & 0.006 & \begin{tabular}{|l|l|}
12.08 \\
\end{tabular} & bdl & 0.002 & 1.67 & 0.003 & 0.245 & 0.006 & bdl & bdl & \begin{tabular}{|l|}
0.001 \\
\end{tabular} & \begin{tabular}{|l|}
0.000 \\
\end{tabular} & 0.001 & 100 \\
\hline HLB396 & \begin{tabular}{|l|}
83.9 \\
\end{tabular} & 0.410 & \begin{tabular}{|l|}
0.001 \\
\end{tabular} & \begin{tabular}{|l|}
0.003 \\
\end{tabular} & 17.38 & bdl & 0.004 & 0.09 & 0.111 & 0.336 & 0.018 & bdl & bdl & \begin{tabular}{|l|}
0.001 \\
\end{tabular} & \begin{tabular}{|l|}
0.000 \\
\end{tabular} & bdl & 100 \\
\hline HLB427 & 92.3 & 0.310 & 0.001 & \begin{tabular}{|l|}
0.044 \\
\end{tabular} & \begin{tabular}{|l|}
16.99 \\
\end{tabular} & bdl & 0.003 & 0.39 & 0.001 & 0.241 & 0.083 & bdl & bdl & 0.002 & 0.001 & bdl & 100 \\
\hline HLB461 & \begin{tabular}{|l|}
89.9 \\
\end{tabular} & 0.370 & \begin{tabular}{|l|}
0.007 \\
\end{tabular} & \begin{tabular}{|l|}
0.053 \\
\end{tabular} & 22.13 & bdl & 0.005 & 0.13 & 0.001 & 9.512 & 0.019 & bdl & bdl & \begin{tabular}{|l|}
0.001 \\
\end{tabular} & 0.000 & bdl & 100 \\
\hline HLB500 & 87.6 & 0.480 & 0.000 & 0.012 & \begin{tabular}{|l|}
10.94 \\
\end{tabular} & bdl & 0.004 & 0.45 & 0.004 & 0.302 & 0.012 & bdl & bdl & \begin{tabular}{|l|}
0.001 \\
\end{tabular} & 0.000 & bdl & 100 \\
\hline RIM001 & \begin{tabular}{|l|}
77.7 \\
\end{tabular} & 0.130 & 0.001 & 0.060 & 14.34 & bdl & 0.321 & 0.87 & 0.090 & 0.388 & 0.001 & bdl & bdl & bdl & 0.000 & 0.001 & 100 \\
\hline RIM004 & 91.4 & \begin{tabular}{|l|}
0.001 \\
\end{tabular} & \begin{tabular}{|l|}
0.001 \\
\end{tabular} & \begin{tabular}{|l|}
0.055 \\
\end{tabular} & 6.88 & bdl & 0.279 & 0.14 & 0.036 & 0.056 & 0.001 & bdl & bdl & bdl & \begin{tabular}{|l|}
0.000 \\
\end{tabular} & bdl & 100 \\
\hline RIM007 & \begin{tabular}{|l|}
78.4 \\
\end{tabular} & 0.070 & 0.000 & \begin{tabular}{|l|}
0.020 \\
\end{tabular} & \begin{tabular}{|l|}
0.04 \\
\end{tabular} & bdl & 2.484 & 0.09 & 0.045 & 0.483 & 0.012 & bdl & bdl & bdl & 0.000 & 0.001 & 100 \\
\hline RIM013 & \begin{tabular}{|l|}
79.0 \\
\end{tabular} & 0.050 & 0.000 & \begin{tabular}{|l|}
0.015 \\
\end{tabular} & \begin{tabular}{|l|}
11.51 \\
\end{tabular} & bdl & 0.144 & 0.04 & 0.028 & 0.339 & 0.001 & bdl & bdl & bdl & 0.000 & bdl & 100 \\
\hline RIM032 & 90.4 & bdl & 0.003 & 0.039 & 20.82 & bdl & 0.082 & 2.00 & 0.049 & 0.047 & 0.001 & bdl & bdl & bdl & 0.000 & bdl & 100 \\
\hline RIM033 & \begin{tabular}{|l|}
77.6 \\
\end{tabular} & bdl & \begin{tabular}{|l|}
0.000 \\
\end{tabular} & \begin{tabular}{|l|}
0.020 \\
\end{tabular} & \begin{tabular}{|l|}
20.47 \\
\end{tabular} & bdl & 0.338 & 0.86 & 0.010 & 0.245 & 0.000 & bdl & bdl & bdl & \begin{tabular}{|l|}
0.000 \\
\end{tabular} & bdl & 100 \\
\hline RIM035 & 79.0 & bdl & \begin{tabular}{|l|}
0.001 \\
\end{tabular} & \begin{tabular}{|l|}
0.051 \\
\end{tabular} & 15.45 & bdl & 0.303 & 1.40 & 0.047 & 0.698 & 0.002 & bdl & bdl & bdl & \begin{tabular}{|l|}
0.000 \\
\end{tabular} & 0.000 & 100 \\
\hline HRZ022 & \begin{tabular}{|l|}
76.9 \\
\end{tabular} & bdl & 0.001 & \begin{tabular}{|l|}
0.091 \\
\end{tabular} & bdl & \begin{tabular}{|l|}
0.000 \\
\end{tabular} & 0.042 & 8.21 & 0.038 & 0.084 & 0.000 & 0.002 & 0.000 & bdl & bdl & bdl & 100 \\
\hline TRS 002 & \begin{tabular}{|l|}
75.9 \\
\end{tabular} & 0.060 & \begin{tabular}{|l|}
0.001 \\
\end{tabular} & \begin{tabular}{|l|}
0.084 \\
\end{tabular} & 2.04 & 0.013 & 0.057 & 8.09 & 0.063 & 0.113 & 0.000 & 0.013 & 0.002 & bdl & bdl & bdl & 100 \\
\hline TRS 003 & \begin{tabular}{|l|}
78.4 \\
\end{tabular} & 0.350 & 0.008 & 0.060 & 17.86 & 0.041 & 0.027 & 0.62 & 0.031 & 0.570 & 0.000 & 0.007 & 0.000 & bdl & bdl & bdl & 100 \\
\hline ZAV C64 & 74.9 & 0.990 & 0.001 & 0.082 & 21.78 & 0.000 & 0.046 & 0.04 & 0.027 & 0.286 & 0.000 & 0.013 & 0.002 & bdl & bdl & bdl & 100 \\
\hline RIM009 & 82.2 & bdl & 0.005 & bdl & 20.33 & bdl & 1.232 & 0.10 & 0.024 & 0.543 & 0.029 & bdl & bdl & 0.015 & \begin{tabular}{|l|}
0.004 \\
\end{tabular} & 0.001 & 100 \\
\hline HLB161 & 81.4 & 0.90 & 0.001 & 0.003 & 21.70 & bdl & 0.003 & 1.21 & 0.013 & 0.231 & 0.020 & bdl & bdl & 0.002 & 0.000 & 0.001 & 100 \\
\hline HLB388 & 87.1 & 0.100 & 0.001 & 0.024 & 21.12 & bdl & 0.005 & 0.15 & 0.005 & 0.424 & 0.012 & bdl & bdl & 0.001 & 0.000 & 0.001 & 100 \\
\hline RIM003 & 80.8 & 0.950 & 0.003 & 0.050 & 23.23 & bdl & 0.656 & 0.03 & 0.034 & 0.616 & 0.003 & bdl & bdl & bdl & 0.000 & 0.001 & 100 \\
\hline RIM019 & 76.4 & 0.130 & \begin{tabular}{|l|}
0.001 \\
\end{tabular} & 0.012 & 9.45 & bdl & 0.331 & 4.31 & 0.130 & 0.137 & 0.002 & bdl & bdl & bdl & 0.000 & 0.000 & 100 \\
\hline RIM022 & 76.9 & 0.490 & 0.000 & 0.018 & 0.03 & bdl & 1.222 & 9.32 & 0.011 & 0.127 & 0.001 & bdl & bdl & bdl & 0.000 & 0.002 & 100 \\
\hline RIM028 & 76.2 & 0.030 & 0.000 & 0.007 & 21.10 & bdl & 0.262 & 0.64 & 0.085 & 0.136 & 0.002 & bdl & bdl & bdl & 0.000 & 0.000 & 100 \\
\hline RIM034 & 75.8 & \begin{tabular}{|l|}
0.110 \\
\end{tabular} & 0.000 & \begin{tabular}{|l|}
0.020 \\
\end{tabular} & 22.90 & bdl & 0.517 & 0.27 & 0.010 & 0.363 & 0.000 & bdl & bdl & bdl & 0.000 & 0.001 & 100 \\
\hline RIM002 & 80.4 & bdl & \begin{tabular}{|l|}
0.003 \\
\end{tabular} & bdl & \begin{tabular}{|l|l}
18.97 \\
\end{tabular} & bdl & 0.925 & 0.89 & 0.010 & 0.090 & 0.012 & bdl & bdl & \begin{tabular}{|l|}
0.011 \\
\end{tabular} & \begin{tabular}{|l|}
0.002 \\
\end{tabular} & 0.000 & 100 \\
\hline RIM029 & \begin{tabular}{|l|}
79.2 \\
\end{tabular} & bdl & \begin{tabular}{|l|}
0.002 \\
\end{tabular} & bdl & 21.66 & bdl & 0.434 & 0.25 & 0.008 & 0.234 & 0.009 & bdl & bdl & \begin{tabular}{|l|}
0.006 \\
\end{tabular} & \begin{tabular}{|l|}
0.001 \\
\end{tabular} & 0.001 & 100 \\
\hline HLB356 & \begin{tabular}{|l|}
77.2 \\
\end{tabular} & \begin{tabular}{|l|}
0.270 \\
\end{tabular} & \begin{tabular}{|l|}
0.000 \\
\end{tabular} & \begin{tabular}{|l|}
0.026 \\
\end{tabular} & 21.37 & bdl & 0.002 & 2.28 & 0.013 & 0.187 & 0.020 & bdl & bdl & \begin{tabular}{|l|}
0.001 \\
\end{tabular} & \begin{tabular}{|l|}
0.001 \\
\end{tabular} & 0.000 & 100 \\
\hline RIM010 & 77.2 & bdl & 0.000 & 0.055 & \begin{tabular}{|l|}
19.01 \\
\end{tabular} & bdl & 0.496 & 1.55 & 0.162 & 0.214 & 0.001 & bdl & bdl & bdl & 0.000 & 0.002 & 100 \\
\hline RIM036 & \begin{tabular}{|l|}
77.1 \\
\end{tabular} & 0.100 & 0.000 & \begin{tabular}{|l|}
0.017 \\
\end{tabular} & 20.69 & bdl & 0.048 & 2.91 & 0.012 & 0.768 & 0.000 & bdl & bdl & bdl & 0.000 & 0.001 & 100 \\
\hline
\end{tabular}

Table 3. Chemical composition in wt. $\%$ of the analysed samples. 


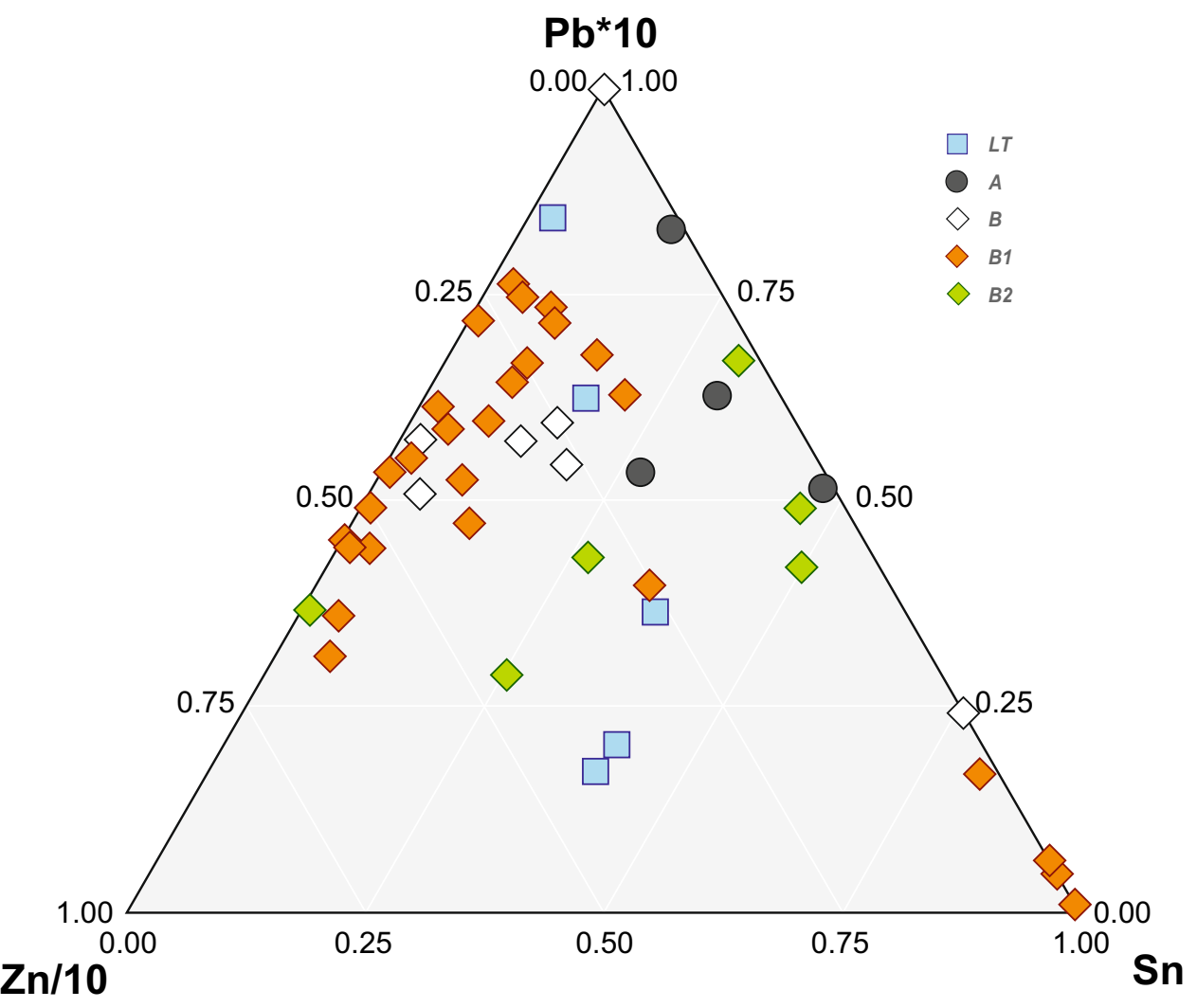

Figure 3. Ternary $\mathrm{Pb}-\mathrm{Zn}-\mathrm{Sn}$ plot for the Bohemian brass samples from this study categorised according to their dating. Zinc content is divided by a factor of ten, whereas the $\mathrm{Pb}$ content is multiplied by factor of ten. For categorisation according to the cultural groups see Suppl. Figure 1.

Those were especially the visual qualities of brass that were favoured for producing costume parts such as brooches, rings, pins and belts made both in Roman and Barbarian cultural environments. However, geochemical data for metal finds from the Barbaricum are still sparse, particularly those of the local (i.e. Germanic) provenance. In parallel to such compositional evolution on the Roman side, lower $\mathrm{Zn}$ contents in Barbarian artefacts measured here can be attributed to local mixing and recycling of the imported objects. In addition, a repeating pattern of small contents of Sn was observed randomly occurring in high Zn-brass artefacts throughout the entire period except for the earliest and youngest samples (Table 3).

In order to reveal further details about the manufacturing of brass in the indigenous territories, the assemblage analysed in this study was compared with chronologically and typologically compatible data from published reports. Given the overall purity of the analysed alloys in terms of chemical composition, we can exclude mixing of brass with $\mathrm{Sn}$ bronzes and leaded brass/bronze alloys known from the Roman $\mathrm{Cu}$-alloy production for most of our samples with high $\mathrm{Zn}$ content ${ }^{56}$. A scenario of a 'melting pot of all $\mathrm{Cu}$-alloys' may thus be definitively excluded. However, mixing of brass with a close chemical fingerprint is still plausible but, in such case, the $\mathrm{Zn}$ content would be lowere ${ }^{4}$. In case of artefacts with significantly lower $\mathrm{Zn}$ contents (2-9 wt. \%), we may assume (i) technological experimenting given the inexperience with new material in the earliest Roman period (R A; Fig. 3; Suppl. Figure 2b), and/or (ii) repeated recycling of various $\mathrm{Cu}$-alloys, including brass, tin-brass, leaded brass etc. The later process leads to a gradual depleting of alloying components with a lower evaporation point, such as Zn and Sn. In our group of samples this seem to occur more towards the end-period (R B2; Fig. 3; Suppl. Figure $2 \mathrm{~b}$ ) and correspond with the contemporary findings from elsewhere within the territories with imported Roman brass ${ }^{64}$. This chemical pattern can also indicate gradual lowering of the quality of the used materials that was also reported in the case of Roman coins from the same period ${ }^{65}$.

Comparison with contemporary assemblages. The comparative dataset of the chemical compositions includes early Roman finds from Bohemia (NAA method ${ }^{28}$ ), and Cambodunum (AAS method ${ }^{66}$ ), both analysed in the 1990s, brass brooches from the territory of Slovenia (PIXE method ${ }^{9,10}$ ), and brass staters from Gaul $\left(\right.$ FNAA $^{67}$ ). Due to the currently leading hypothesis about the Roman brass used for the fabrication of the costume parts in the Barbaricum, chemical data from the brass coinage ${ }^{65}$ were used for a more detailed comparison. The latest data for the Roman brass coinage were obtained by PIXE ${ }^{68}$ and, unfortunately, do not provide sufficiently accurate results for the comparison. When comparing the earliest brass artefacts from the first century $\mathrm{BC}$, the main alloying components $(\mathrm{Zn}, \mathrm{Sn}, \mathrm{Pb})$ reveal a cluster of late Iron Age brass staters of VERCA and Vercingetorix CAS series because of their lower mean $\mathrm{Zn}$ contents (ca. $12.2 \mathrm{wt}$ \%; Fig. 7). The difference between 
A

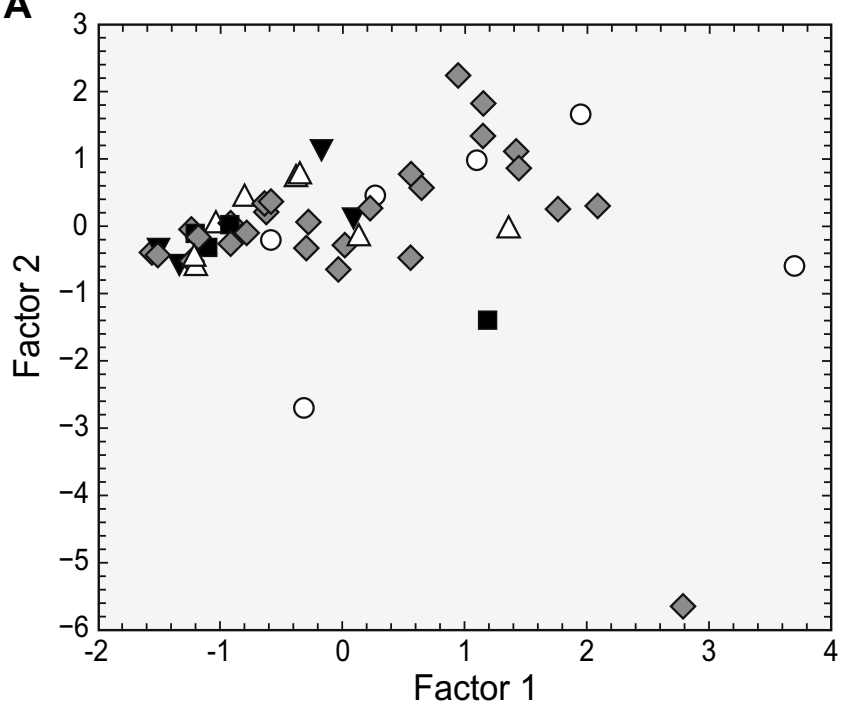

B

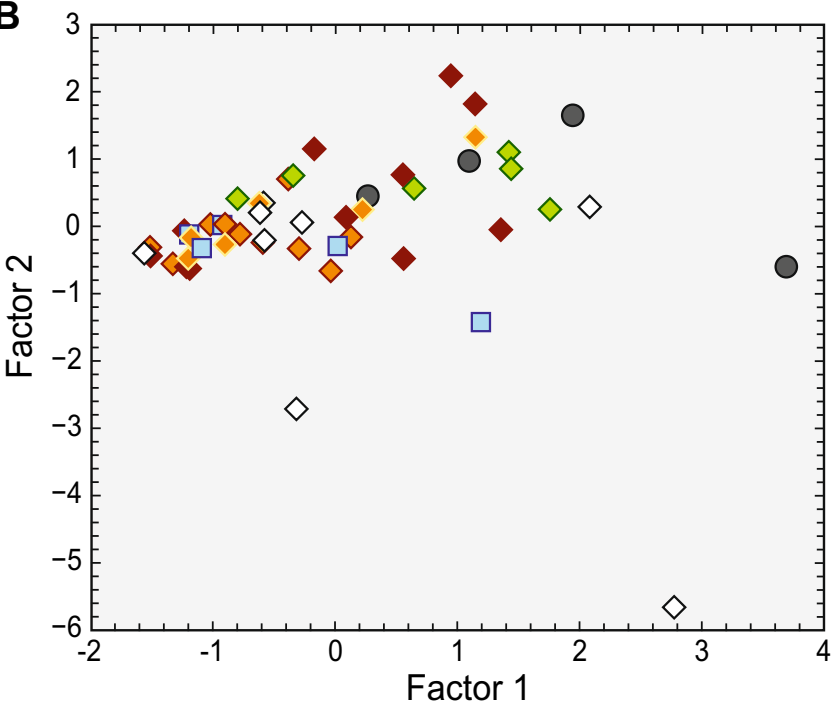

\section{Cultural group}

LT-Brass

$O I$

$\diamond L$

$\triangle N$

$\nabla w$

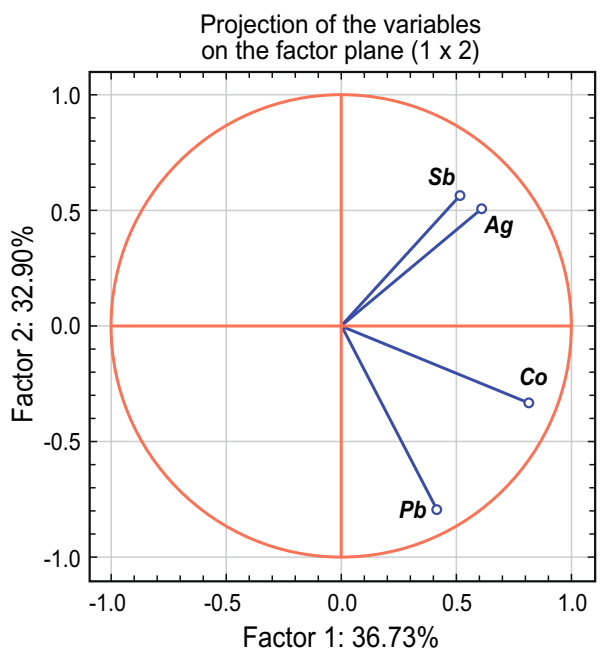
Archae
dating
$\square L T$
○ $A$
$\diamond B$
$\diamond B 1$
$\checkmark B 1 a$
B1b
$\diamond B 2$

Figure 4. Plot with results of principal component analysis based on minor/trace elements $(\mathrm{Pb}, \mathrm{Co}, \mathrm{Sb}, \mathrm{Ag})$ for the Bohemian brass artefacts from this study. Factor 1 versus Factor 2 is categorised according to the cultural groups (A) and dating (B). The inset panel shows variables factor map.

coins and other brass artefacts of the assemblages mentioned above is probably due to chronology because the 'pure' brass, with high $\mathrm{Zn}$ contents (> $15 \mathrm{wt} . \%$ ), and low contents of $\mathrm{Sn}$ and $\mathrm{Pb}$ (sum below 0.5 wt.\%) appeared no earlier than around the Augustan period. Besides, there is evidence of $\mathrm{Zn}$-rich brass in the second half of the first century BC (phase R A; Suppl. Figure 2, 3).

A second PCA with only selected trace elements only (Co, Ni, Sb, Ag) was carried out including the comparative datasets. To avoid inconsistency, the dataset was reduced solely to brooches. This step further enhanced the chronological compatibility among the typological groups of the artefacts. Also, in the archaeological categorisation of the groups, several trends were revealed (Suppl. Figure 4a). Similarly to 'N' samples from Bohemia, also Norican brooches tend to contain more Ag, which is paralleled by higher contents of Sb, thus indicating fahlore copper $^{69,70}$ used for their fabrication. The most significant variability in the trace element composition was observed for the local items ('L'). Chronologically speaking, a notable heterogeneity in the chemical composition may be observed in the phase R B1a compared to the following phase R B1b (Suppl. Figure 4b). A specific group of the artefacts of the Norican tradition from the phase R B2 forms a tight cluster in both plots. These findings indicate rather heterogeneous supply patterns of brass in the beginnings of the trade contacts between the early Empire and the Germanic communities, compared to the late Republic and Celtic agglomerations of the second and first century $\mathrm{BC}$ on the one hand and late first century $\mathrm{AD}$ on the other.

When these results are compared with the Roman copper AES coinage, a weak correlation between the part of the Bohemian samples with elevated Sb and Ag levels (Sb 0.01-0.2 wt. \%; Ag 0.001-1.5 wt. \%.) and the AES coinage elemental pattern group III (EPG III), characterised also by increased levels of Sb $(0.02-0.1 \mathrm{wt}$. \%) and 
A
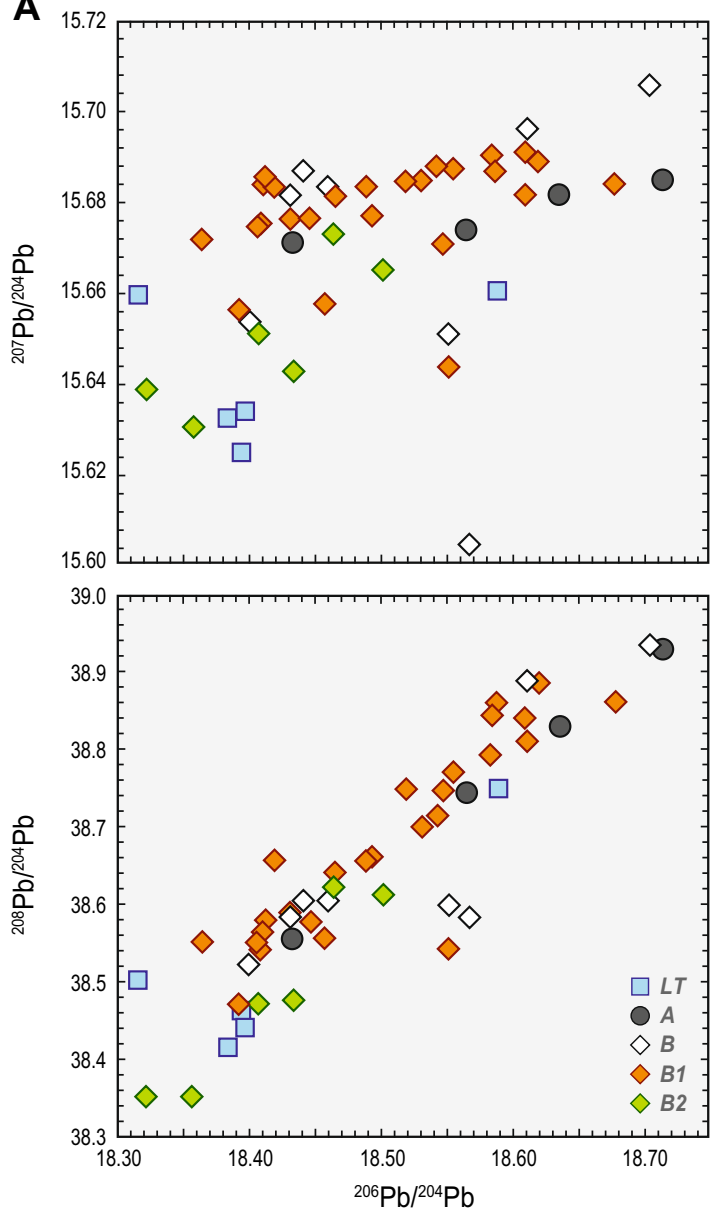

B
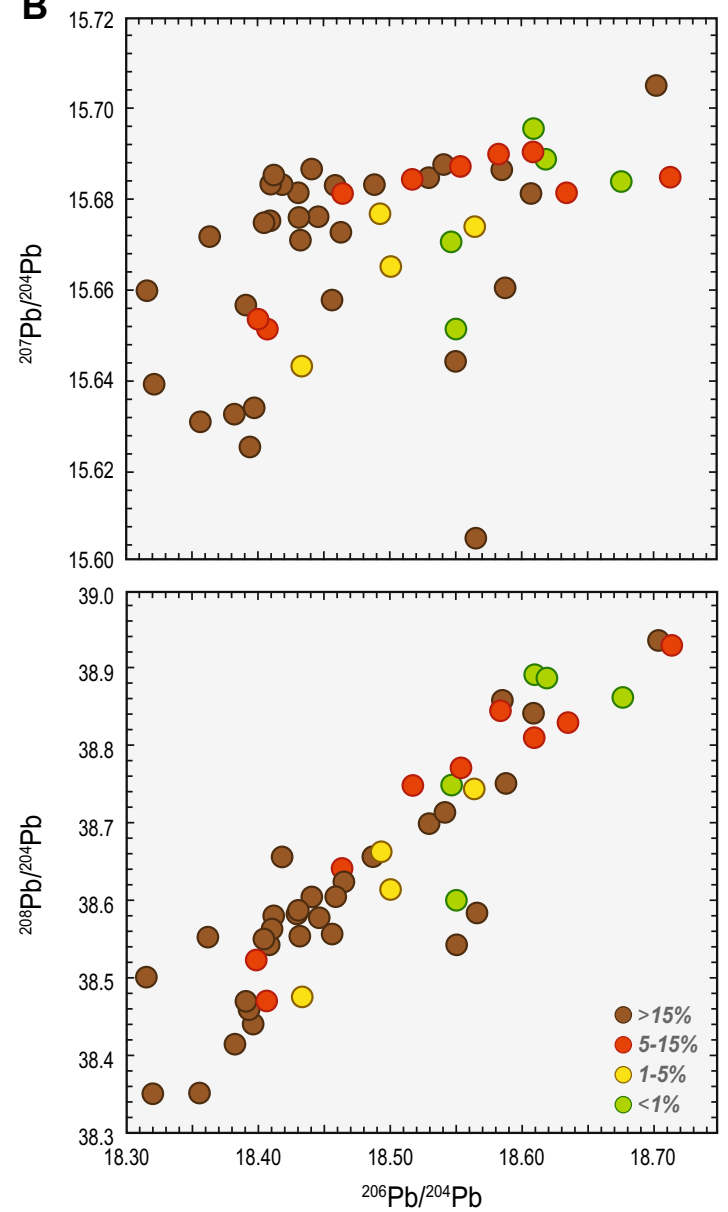

Figure 5. The $\mathrm{Pb}$ isotope systematics of the Bohemian brass artefacts from this study categorised according to the archaeological dating (A) and Zn contents (B). For categorisation according to the cultural groups see Fig. 6.

$\mathrm{Ag}\left(0.03-0.7\right.$ wt. \%), is apparent ${ }^{13}$. Similar Sb- and Ag-rich copper AES coinage is also specific for the Lyon altar series I (LAS I) AES coinage ${ }^{71}$.

The comparison of brass artefacts with $>5 \mathrm{wt} . \% \mathrm{Zn}$ from Bohemia and Cambodunum ${ }^{66}$ with the Roman brass coinage ${ }^{65}$ is based on the systematics of Sb and Ag (Fig. 8). It clearly shows the incompatibility between the local brass artefacts and the Roman sestertii. Due to the different analytical approaches to obtain the compositional data, the results must be treated with caution. Also, a significant variability of the Roman metal supply for the coin production [cf. ${ }^{13}$ ] should be considered. Therefore, for successful future provenance studies, a targeted archaeometric analysis of the Roman coins is vital.

A brooch with an unusually high Ag content (20.8 wt. \%) is, generally speaking, uncommon-even in the context of the broad spectrum of Early Roman finds from Central Europe ${ }^{29,66}$. Nonetheless, there are artefacts known from the contemporary cemeteries to had been manufactured from pure Ag, and particularly this type of brooch (Almgren 24) is the one most frequently fabricated artefacts from precious metals ${ }^{48,72}$. Considering the technologically advanced metallurgy - both Roman and Barbarian - unintentional contamination caused by the accidental use of Ag-rich ore is considered rather implausible. Local manufacturing of Ag-rich brooches by deliberate alloying with Ag thus remains a possible explanation.

Provenance analysis - mineral exploitation and raw resources in the Early Roman period. Lead isotope analysis has become a conventional method for tracing the archaeological artefacts containing $\mathrm{Pb}$ to their possible geological origins, i.e. the ores the artefacts were fabricated from ${ }^{73,74}$. The provenance analysis testing the consistency between the samples and the known ore deposits was carried out using a combination of the conventional biplots and the Euclidean (ED) and Mahalanobis (MD) distance algorithms ${ }^{21}$. The same approach was then applied to compare the contemporary bronze and brass assemblages of various cultural backgrounds. The ED algorithm has initially been suggested by $\operatorname{Stos}^{75}$ as a simple metric to compare how far the point distributions are from one another in a multivariate space defined by individual $\mathrm{Pb}$ isotope signals. While the ED algorithm is currently widely used, it is advised to be complemented with MD in which the effects of the shape, scale and trend of the distribution of the data are accounted for ${ }^{76}$. Therefore, the metric can measure the distance from a data point to distribution in the multivariate space and can account for the distance of points as well as for the linear trends in the data and distributions of the data clouds. Plots derived using such an approach (Fig. 9; 

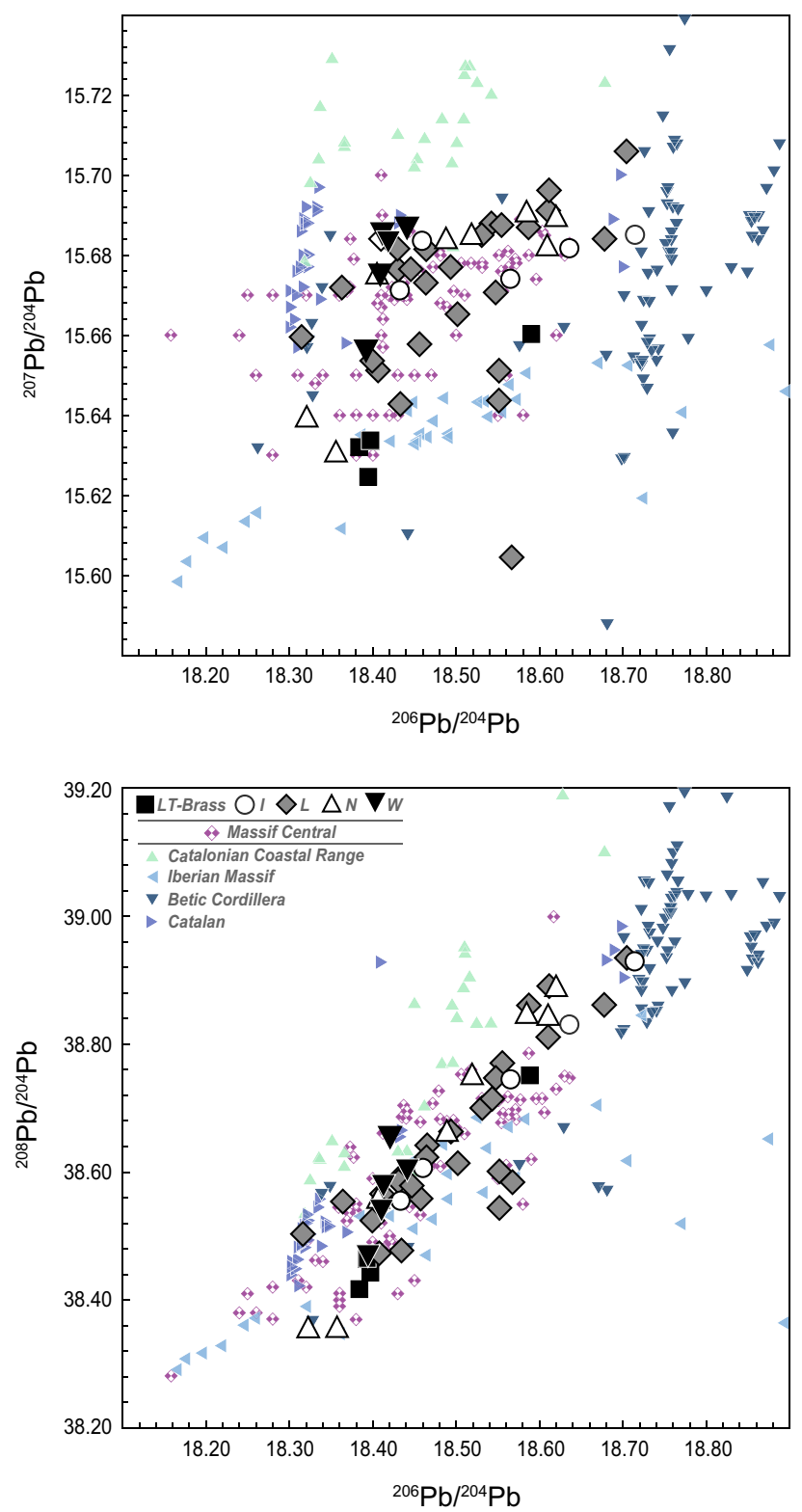

Figure 6. The $\mathrm{Pb}$ isotope systematics of ore sources from the northwest Mediterranean zone $2,16,20,21,35,59-61$ and the Bohemian brass (this study) artefacts categorised according to the cultural groups.

Suppl. Figure 5) are then used to predict the allocation of the analysed brass artefacts from Bohemia in the comparative datasets. Due to considerable overlaps in the data distributions of different ore deposits, we note that the predictive value of $\mathrm{ED}+\mathrm{MD}$ can vary among distinctive sources.

Because $92 \%(\mathrm{n}=50)$ of our samples have a low $\mathrm{Pb}$ content $(<1 \mathrm{wt} . \%)$, we do not consider the sampled alloys to have been deliberately leaded ${ }^{56,64,77}$. The $\mathrm{Pb}$ isotope systematics thus appear to reflect the intrinsic mineralderived lead than can be used for reliable prediction of their provenance. The best level of consistency for most of our samples is observed with polymetallic deposits from the Massif Central (Fig. 6; Suppl. Figures 5, 6). These results were verified by both the ED and MD algorithms; however, the outliers in the Massif Central ore dataset provided a less pronounced consistency than the standard biplot. There is also a possibility of mixing the sources from various deposits, namely the Mediterranean (Iberia, Sardinia, Macedonia, or Attica) or the Alpine (namely the south-eastern Alps and the Inn Valley; Suppl. Figures 5, 6). The Alpine signal is the most apparent in the 'N' category. British source ores did not come into consideration until AD 43 when Britain came under the Roman control and data were thus omitted for historical reasons.

Additional chemical data from the early Roman imperial $\mathrm{Pb}$ artefacts were included in the comparative analysis: the Augustan $\mathrm{Pb}$ water pipes from Pompeii [code 'Pb pipes' ${ }^{\prime 7}{ }^{7}$ ] and $\mathrm{Pb}$ ingots from the shipwreck of Sainte-Maries-de-la-Mer [code ' $\mathrm{Pb}$ ingots' ${ }^{\prime 59}$ ]. A similar analytical match and subsequent historical interpretation 


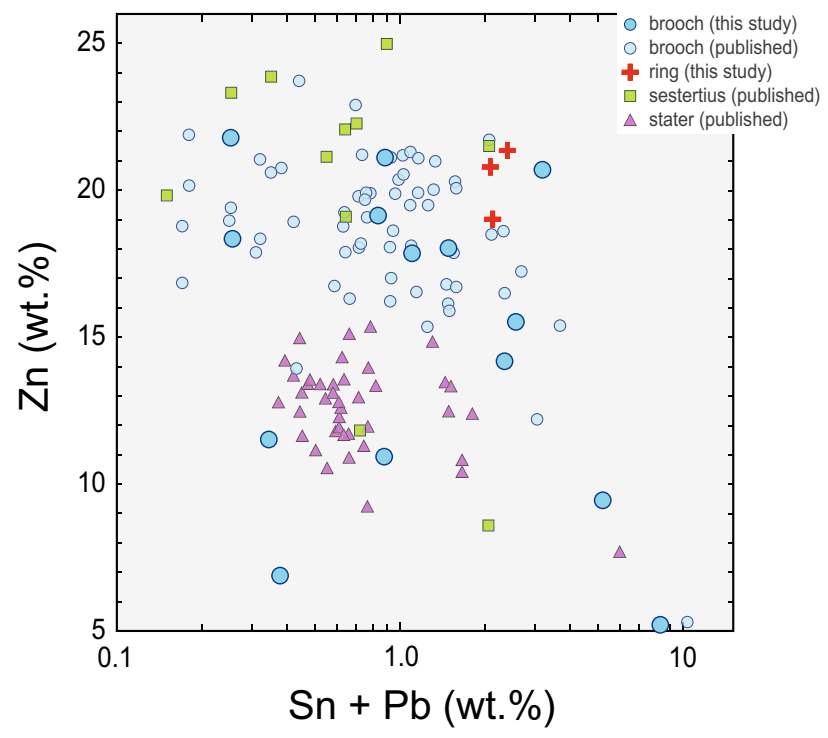

Figure 7. Plot of $\mathrm{Zn}$ verus $\mathrm{Sn}+\mathrm{Pb}$ contents (in wt. \%) of the earliest brass artefacts from the first century BC. For categorisation according to dating see Suppl. Figure 3 Sources: ${ }^{9,10,66}+$ this study.

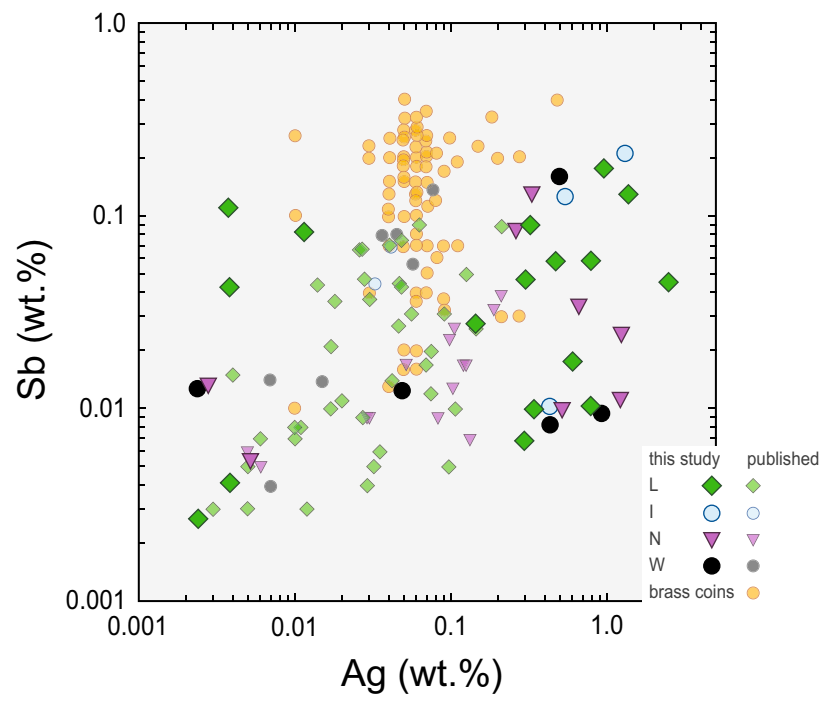

Figure 8. Plot of $\mathrm{Sb}$ versus $\mathrm{Ag}$ contents (in wt. \%) of brass artefacts with $>5$ wt. $\% \mathrm{Zn}$ from Bohemia and Cambodunum with the Roman brass coinage categorised according to the cultural and chronological groups. Sources: this study; ${ }^{65,66}$.

favouring the Massif Central deposits were suggested for brass ingots from the Aléria shipwreck [code 'Cu- $\mathrm{Zn}$ Ingot'; $\left.{ }^{2}\right]$.

Because no $\mathrm{Pb}$ isotope data for the artefacts of the 'Barbarian' provenance are available, only the early Roman Imperial datasets could be included in the comparative analysis. Regarding the provenance of $\mathrm{Cu}$, there is an extensive corpus of comparative data from the Roman AES coinage ${ }^{14,71}$ and Cu ingots of the Sud-Lavezzi 2 Bonifacio wreck from the beginning of the first century $\mathrm{AD}^{15}$. Finally, since we aimed to reveal a possible consistency between the Germanic finds and the preceding late Iron Age artefacts, bronze artefacts mainly from the first century BC ('Oppida' set) were also included in the comparative dataset ${ }^{20,21,35}$ to detect potential looting of the abandoned Celtic oppida by the newly incoming Germanic populations.

The results show that the $\mathrm{Pb}$ isotope compositions of most of the Early Roman samples in this study are generally inconsistent with late Iron Age finds (cf. results of ED and MD, Fig. 9; Suppl. Figure 7). A subset of samples, consisting mostly of artefacts dated to the La Tène period or late first and/or second century AD with less radiogenic ${ }^{207} \mathrm{~Pb} /{ }^{204} \mathrm{~Pb}$ and ${ }^{206} \mathrm{~Pb} /{ }^{204} \mathrm{~Pb}$ ratios are closer to ore deposits in Germany (Suppl. Figure 6), and are consistent with Roman $\mathrm{Cu}$ coins, $\mathrm{Cu}-\mathrm{Zn}, \mathrm{Pb}$ ingots and part of the copper AES coinage from the LAS I. There appears to 


\section{A Euclidean distance}

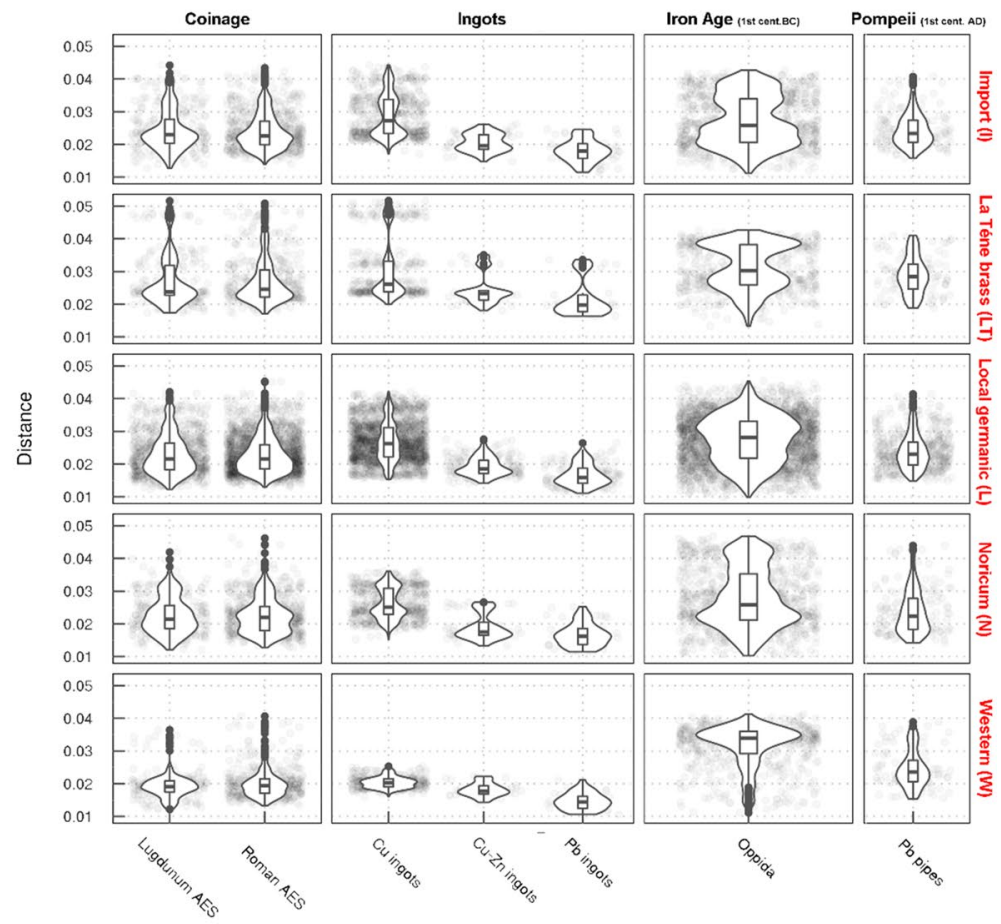

B Mahalanobis distance

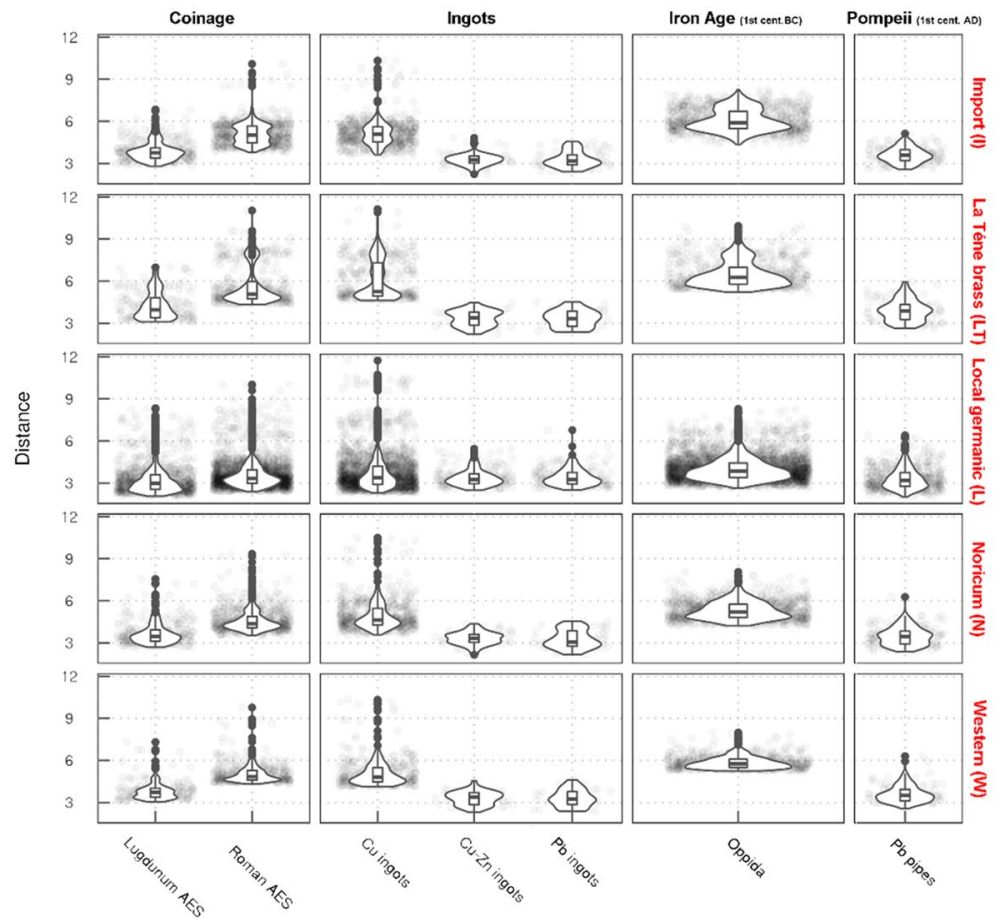

Figure 9. Euclidean (ED) and Mahalanobis (MD) distances between $\mathrm{Pb}$ isotope ratios of various sets of the analysed artefacts from the Early Roman period (red labels) and the comparative datasets of bronze and brass artefacts (coinage, ingots, Iron Age objects from the oppida, Pompeii objects; for references, see main text). The graph shows the density distributions ('density violin plots') according to their distance. Unlike ED, the MD distributions also take into consideration the shape of the data clouds and their trends. The closer to zero the higher the probability of the analytical match. Sources: see description in the main text + this study. 
be a consistency with the preliminary findings of Roman copper/brass alloys from Elsfleth-Hogenkamp dated to the second - third century AD as well, but we note that the report of Merkel lacks analytical data and we cannot make any further conjectures ${ }^{77}$. No analytical match with the Cu bars from Sud-Lavezzi 2 Bonifacio was observed, although the $\mathrm{Cu}$ bars might be a very convenient and contemporary source of copper. The samples with low Zn contents (Fig. 3; Suppl. Figure 2) from the R A and R B2 phases, respectively, combined with their tendency towards less radiogenic ${ }^{207} \mathrm{~Pb} /{ }^{204} \mathrm{~Pb}$ ratios (Fig. 5b), are still within the range of the ores from the Massif Central. However, three out of four samples from the early phase (R A) show some proximity towards the south-eastern Iberian zone, most compatible with the late La Tène samples ${ }^{20}$. Sample RIM017 with a lower ${ }^{206} \mathrm{~Pb} /{ }^{204} \mathrm{~Pb}$ ratio contradicting this chronological explanation could equally be dated into the phase R B1 (Tables 2, 3, 4). The LAS $\mathrm{I}$ is consistent with a subset of the Bohemian samples in their $\mathrm{Pb}$ isotope ratios and $\mathrm{Ag}$ contents ${ }^{71}$. A tendency towards less radiogenic ${ }^{207} \mathrm{~Pb} /{ }^{204} \mathrm{~Pb}$ and ${ }^{206} \mathrm{~Pb} /{ }^{204} \mathrm{~Pb}$ ratios may result from the influence of the Iberian Massif (Fig. 6; Suppl. Figure 5,6). The southern Spanish mines are thought to be most important in the organisation of the Roman Cu supply ${ }^{14}$, which is also evidenced by the most chronologically compatible dataset-the imperial AES copper coinage. Data from the AES coinage are partly inconsistent with $\mathrm{Cu}$ ingots, but the variability of $\mathrm{Cu}$ sources corresponds well with the suggested complexity of the $\mathrm{Cu}$ industry of the Roman Empire ${ }^{15}$. In the case of samples from the phase R B2, i.e. after $43 \mathrm{AD}, \mathrm{Pb}-\mathrm{Zn}$ deposits from Great Britain may also come into consideration $\left[\mathrm{cf}^{2}\right]$. Since data from this late phase is rather subordinate in number, further historical analysis, such as the trend comparisons with discussed ore deposits, cannot be performed.

Collectively, there are three most distinctive analytical matches in terms of possible ore resources. All these scenarios are historically plausible and can be thus discussed further:

I. The mixing of Mediterranean sources has been thoroughly discussed for the $\mathrm{Pb}$ pipes from Pompeii, which had $\mathrm{Pb}$ isotope signature close to the samples from this study (Fig. 9; Suppl. Figure 7) ${ }^{78}$. The authors interpreted lead from Pompeii as a mixture of Sardinian, Iberian and Laurion ores; however, as recently pointed out ${ }^{60}$, the possibility of the involvement of the Massif Central ores was initially omitted from the discussion. Considering the original 'mixing scenario', a more satisfying explanation for $\mathrm{Pb}$ in the Pompeiian pipes would favour the Cartago Nova deposits with a minor influence from Sardinian ores ${ }^{60}$.

II. The Alpine origin of brass is unsupported because of the lack of clear historical evidence of Roman copper or lead mining in this region. There is a partial $\mathrm{Pb}$ isotope overlap with the deposits from the Central Alps (Valais) that may be associated with the 'Sallustian' copper, mentioned by Pliny the Elder, and linked to the Haute Savoie (Suppl. Figure 5,6), which was discussed in the context of the chemical composition of Lyon altar series AES coinage. This explanation, however, was abandoned because of the inconsistency of the LAS coinage with the $\mathrm{Pb}$ isotope ratios of given deposits ${ }^{71}$. A subordinate correlation of the chemical composition and $\mathrm{Pb}$ isotope compositions of the ' $\mathrm{N}$ ' category of samples can be considered for geographical reasons, but this consistency is far from being proven.

III. According to Leblanc's ${ }^{79}$ map, the $\mathrm{Pb}-\mathrm{Zn}$ mineralisation in the Massif Central is spread from Les Malines to Lyon, where the production of brass is dated from the middle of the first century AD to the beginning of the second century $\mathrm{AD}^{80,81}$. The south-eastern part of the Massif Central is rich in various Cu-bearing ore bodies with specific combinations of the trace elements, for example, ophiolites ( $\mathrm{Ni}, \mathrm{Co}, \mathrm{Ag}$ ), pyrite ores (Ag, Au), Permo-Triassic (As, Pb, Ag), and Hercynian veins ( $\mathrm{Sb}$-Ag-Pb) with the Salsigne type mineralisation (As, Bi, Au ${ }^{79}$. The connection of the polymetallic deposits in the Massif Central ${ }^{61}$ with the Roman lead metallurgy has been suggested earlier ${ }^{59}$. To support this argumentation, six samples in this study that are made of Sn-bronze, $\mathrm{Pb}$-bronze or Ag-rich bronze, i.e. without any cementation process possibly taking place, still have their $\mathrm{Pb}$ isotope compositions consistent with the Massif Central ores, and we may thus assume that even $\mathrm{Cu}$ was extracted in the same region. A specific mining site, consistent with the $\mathrm{Pb}$ isotopic data from this study, cannot be assigned because the available data cover the entire $\mathrm{Pb}$ isotope diversity of the Massive Central ore deposits ${ }^{60}$. At present, this dataset appears to bear similarity with $\mathrm{Pb}$ isotope values from the Les Malines $\mathrm{Pb}-\mathrm{Zn}$ deposit ${ }^{61}$. Whether the deposits in the Cevénnes area also served as a $\mathrm{Cu}$ source remains uncertain ${ }^{2}$.

Consideration of possible contamination. A particular methodological risk should be considered when comparing brass artefacts with possible $\mathrm{Cu}$ ores because $\mathrm{Zn}$ ores, as an essential constituent of the produced brass, may also contain trace amounts of $\mathrm{Pb}^{2,6,82,83}$. The inclusion of such $\mathrm{Pb}$ may then disturb or obscure the $\mathrm{Pb}$ isotope signature of the intrinsic $\mathrm{Cu}$ source during the cementation process ${ }^{84}$. There is also the uncertainty on how exactly and how much the cementation medium had impacted the trace element composition, which is crucial for the correct interpretation of the chemical composition of the analysed brass artefacts. So far, it is known that at least $\mathrm{Fe}$ and $\mathrm{As}$ can enter $\mathrm{Cu}$ metal during the cementation process ${ }^{84}$. In Roman Imperial workshops, where a very pure $\mathrm{Cu}$ was manufactured due to the advanced refining ${ }^{13}$, the risk of contamination could be exceptionally high. Therefore, it must be acknowledged that the $\mathrm{Pb}$ isotope signal from the samples may point to the $\mathrm{Pb}-\mathrm{Zn}$ source ore instead of the $\mathrm{Cu}$ ore $\left[\mathrm{cf}^{2}\right]$. Furthermore, the hypothetical contamination during the cementation process could strongly influence the comparison of Roman $\mathrm{Cu}$ coins and brass artefacts based on trace elements such as Sb and Ag. These notions, however, require carefully controlled metallurgical experiments. We assume that the cementation process was carried out using $\mathrm{Zn}$ in $\mathrm{Pb}-\mathrm{Zn}$ ore rather than $\mathrm{Zn}$ in the form of $\mathrm{ZnO}$, typically developed in furnaces during the pyrotechnological process [cf. ${ }^{6}$. The $\mathrm{Pb}$ contents in brass samples from this study are significantly higher than those in the LAS I coinage ${ }^{71}$, representing at present the purest available copper from the Massif Central.

The possibility of $\mathrm{Zn}$ source for Roman brass production was recently further discussed by S. Merkel ${ }^{77}$, who analysed the $\mathrm{Zn}$ ores from Dossena in Northern Italy by means of $\mathrm{Pb}$ isotope analysis. A slight overlap in $\mathrm{Pb}$ 


\begin{tabular}{|c|c|c|c|c|c|c|c|}
\hline Lab. No & ${ }^{206} \mathrm{~Pb} /{ }^{204} \mathrm{~Pb}$ & ${ }^{207} \mathrm{~Pb} /{ }^{204} \mathrm{~Pb}$ & ${ }^{208} \mathrm{~Pb} /{ }^{204} \mathrm{~Pb}$ & ${ }^{207} \mathrm{~Pb} /{ }^{206} \mathrm{~Pb}$ & ${ }^{208} \mathrm{~Pb} /{ }^{206} \mathrm{~Pb}$ & Pb group & Zn group \\
\hline RIM012 & 18.714 & 15.685 & 38.929 & 0.838 & 2.081 & $>1 \%<5 \%$ & $>5 \%<15 \%$ \\
\hline RIM017 & 18.433 & 15.671 & 38.555 & 0.850 & 2.092 & $<1 \%$ & $>15 \%$ \\
\hline RIM020 & 18.441 & 15.687 & 38.606 & 0.850 & 2.094 & $<1 \%$ & $>15 \%$ \\
\hline HLB027 & 18.460 & 15.684 & 38.607 & 0.849 & 2.092 & $>5 \%$ & $>15 \%$ \\
\hline RIM005 & 18.565 & 15.674 & 38.745 & 0.844 & 2.087 & $<1 \%$ & $>1 \%<5 \%$ \\
\hline RIM030 & 18.636 & 15.682 & 38.830 & 0.841 & 2.084 & $<1 \%$ & $>5 \%<15 \%$ \\
\hline RIM006 & 18.431 & 15.676 & 38.589 & 0.850 & 2.094 & $<1 \%$ & $>15 \%$ \\
\hline RIM008 & 18.493 & 15.677 & 38.662 & \begin{tabular}{|l|}
0.847 \\
\end{tabular} & 2.091 & $<1 \%$ & $>1 \%<5 \%$ \\
\hline RIM011 & 18.434 & 15.643 & 38.477 & 0.848 & 2.088 & $<1 \%$ & $>1 \%<5 \%$ \\
\hline RIM014 & 18.704 & 15.706 & 38.936 & 0.840 & 2.082 & $<1 \%$ & $>15 \%$ \\
\hline RIM015 & 18.542 & 15.688 & 38.715 & 0.846 & 2.088 & $<1 \%$ & $>15 \%$ \\
\hline RIM016 & 18.410 & 15.684 & 38.566 & 0.852 & 2.095 & $<1 \%$ & $>15 \%$ \\
\hline RIM018 & 18.502 & 15.665 & 38.614 & 0.846 & 2.087 & $<1 \%$ & $>1 \%<5 \%$ \\
\hline RIM021 & 18.464 & 15.673 & 38.623 & 0.849 & 2.092 & $<1 \%$ & $>15 \%$ \\
\hline RIM023 & 18.364 & 15.672 & 38.554 & 0.853 & 2.100 & $<1 \%$ & $>15 \%$ \\
\hline RIM024 & 18.407 & 15.651 & 38.473 & 0.850 & 2.090 & $<1 \%$ & $>5 \%<15 \%$ \\
\hline RIM025 & 18.316 & 15.660 & 38.504 & 0.855 & 2.103 & $>1 \%<5 \%$ & $>15 \%$ \\
\hline RIM026 & 18.611 & 15.696 & 38.891 & 0.843 & 2.090 & $<1 \%$ & $<1 \%$ \\
\hline RIM027 & $\mathrm{x}$ & $\mathrm{x}$ & $\mathrm{x}$ & $\mathrm{x}$ & $\mathrm{x}$ & & \\
\hline RIM031 & 18.447 & 15.677 & \begin{tabular}{|l|}
38.579 \\
\end{tabular} & 0.850 & 2.092 & $<1 \%$ & $>15 \%$ \\
\hline HLB040 & 18.611 & 15.691 & 38.811 & 0.843 & 2.086 & $<1 \%$ & $>5 \%<15 \%$ \\
\hline HLB155 & 18.431 & 15.682 & 38.585 & 0.851 & 2.094 & $<1 \%$ & $>15 \%$ \\
\hline HLB396 & 18.400 & 15.654 & 38.525 & 0.851 & 2.094 & $<1 \%$ & $>5 \%<15 \%$ \\
\hline HLB427 & 18.555 & 15.688 & 38.771 & 0.845 & 2.090 & $<1 \%$ & $>5 \%<15 \%$ \\
\hline HLB461 & 18.552 & 15.651 & 38.601 & 0.843 & 2.081 & $<1 \%$ & $<1 \%$ \\
\hline HLB500 & 18.465 & 15.682 & 38.642 & 0.849 & 2.093 & $<1 \%$ & $>5 \%<15 \%$ \\
\hline RIM001 & 18.567 & 15.605 & 38.584 & 0.840 & 2.078 & $<1 \%$ & $>15 \%$ \\
\hline RIM004 & 18.548 & \begin{tabular}{|l|}
15.671 \\
\end{tabular} & \begin{tabular}{|l|}
38.748 \\
\end{tabular} & 0.845 & 2.090 & $<1 \%$ & $<1 \%$ \\
\hline RIM007 & 18.457 & 15.658 & 38.559 & 0.848 & 2.089 & $<1 \%$ & $>15 \%$ \\
\hline RIM013 & 18.531 & 15.685 & \begin{tabular}{|l|}
38.700 \\
\end{tabular} & 0.846 & 2.089 & $<1 \%$ & $>15 \%$ \\
\hline RIM032 & 18.678 & 15.684 & 38.861 & 0.840 & 2.081 & $<1 \%$ & $<1 \%$ \\
\hline RIM033 & 18.587 & 15.687 & 38.861 & 0.844 & 2.091 & $<1 \%$ & $>15 \%$ \\
\hline RIM035 & 18.552 & 15.644 & 38.544 & 0.843 & 2.078 & $<1 \%$ & $>15 \%$ \\
\hline HRZ022 & 18.397 & 15.634 & 38.442 & 0.850 & 2.090 & $<1 \%$ & $>15 \%$ \\
\hline TRS 002 & 18.384 & 15.632 & 38.417 & 0.850 & 2.090 & $<1 \%$ & $>15 \%$ \\
\hline TRS 003 & 18.589 & 15.660 & \begin{tabular}{|l|}
38.752 \\
\end{tabular} & 0.842 & 2.085 & $<1 \%$ & $>15 \%$ \\
\hline ZAV C64 & 18.394 & 15.625 & 38.464 & 0.849 & 2.091 & $<1 \%$ & $>15 \%$ \\
\hline RIM009 & 18.584 & 15.690 & 38.845 & 0.844 & 2.091 & $<1 \%$ & $>5 \%<15 \%$ \\
\hline HLB161 & 18.519 & 15.685 & 38.749 & 0.847 & 2.093 & $<1 \%$ & $>5 \%<15 \%$ \\
\hline HLB388 & 18.620 & 15.689 & 38.887 & 0.842 & 2.089 & $<1 \%$ & $<1 \%$ \\
\hline RIM003 & 18.609 & 15.682 & 38.842 & 0.842 & 2.088 & $<1 \%$ & $>15 \%$ \\
\hline RIM019 & 18.322 & 15.639 & 38.352 & 0.853 & 2.094 & $<1 \%$ & $>15 \%$ \\
\hline RIM022 & 18.489 & 15.684 & \begin{tabular}{|l|}
38.658 \\
\end{tabular} & 0.848 & 2.091 & $<1 \%$ & $>15 \%$ \\
\hline RIM028 & 18.357 & 15.630 & 38.353 & 0.851 & 2.090 & $<1 \%$ & $>15 \%$ \\
\hline RIM034 & 18.406 & 15.675 & 38.554 & 0.851 & 2.095 & $<1 \%$ & $>15 \%$ \\
\hline RIM002 & $\mathrm{x}$ & $\mathrm{x}$ & $\mathrm{x}$ & $\mathrm{x}$ & $\mathrm{x}$ & $<1 \%$ & $>15 \%$ \\
\hline RIM029 & 18.412 & 15.686 & 38.581 & 0.852 & 2.096 & $<1 \%$ & $>15 \%$ \\
\hline HLB356 & 18.419 & 15.684 & \begin{tabular}{|l|l}
38.658 \\
\end{tabular} & \begin{tabular}{|l|}
0.851 \\
\end{tabular} & 2.099 & $<1 \%$ & $>15 \%$ \\
\hline RIM010 & \begin{tabular}{|l|}
18.409 \\
\end{tabular} & $\mid 15.675$ & 38.543 & \begin{tabular}{|l|}
0.851 \\
\end{tabular} & 2.094 & $<1 \%$ & $>15 \%$ \\
\hline RIM036 & \begin{tabular}{|l|}
18.392 \\
\end{tabular} & \begin{tabular}{|l|}
15.656 \\
\end{tabular} & 38.472 & 0.851 & 2.092 & $<1 \%$ & $>15 \%$ \\
\hline
\end{tabular}

Table 4. Analysed samples with values of $\mathrm{Pb}$ isotope ratios.

isotope compositions of the Dossena Zn ores with the oldest (LT) and the youngest artefacts (R B2) in our sample suite with the tendency towards less radiogenic ${ }^{207} \mathrm{~Pb} /{ }^{204} \mathrm{~Pb}$ and ${ }^{206} \mathrm{~Pb} /{ }^{204} \mathrm{~Pb}$ ratios can be observed (Fig. 5a; Suppl. Figure 5, 6). However, the majority of new data from this study are inconsistent with the $\mathrm{Zn}$ ores presented in this study. Collectively, we posit that the Massif Central ores still represent the most plausible source of $\mathrm{Zn}$. 
Roman brass production in the Massif Central area. Archaeological evidence for copper mining in the southern Massif Central during the Roman period is still rare; however, two sites in the Cavénes area served as $\mathrm{Cu}$ mines during the late first century BC and the early Imperial period ${ }^{85}$. One deposit around Carcassone, exploited during the later Roman Republic (second and first century BC), has also been documented ${ }^{71,86}$. In general, there always is a possibility of missing archaeological evidence of past extraction activities due to medieval and later mining that may have obscured or eradicated the traces of earlier exploitation. Therefore, clear evidence of the Gallic metal supplies is still missing ${ }^{17}$.

The best evidence for the early Roman (i.e. Augustan period) mining in the Massif Central is the $\mathrm{Pb}$ isotope analysis of the AES coinage of the so-called Lyon altar series $\mathrm{I}^{71}$, supposedly originating in the Cévennes part of the Massif Central. Despite the fact that a part of the Roman brass coin production took place in the Lugdunum (Lyon) mint $^{71}$, similarly to $\mathrm{Pb}$ ingots of Santa Maria and partially also to $\mathrm{Pb}$ pipes from Pompeii, an Iberian origin was initially expected. However, as the chemical analysis of further Lyon altar series coins (the LAS II collection of the AES coinage) indicates, the Gallic production alone might not have been sufficient for the great demand for $\mathrm{Cu}$ during the reign of Augustus, and another $\mathrm{Cu}$ source (possibly of the Iberian origin) was thus used for this other series of ases $^{71}$. From the historical perspective, there has been a suggestion that copper used for coins of the LAS I may have been the 'Livian' Gallic copper, mentioned by Pliny the Elder, as one that was quickly depleted ${ }^{71}$.

It should be noted that also other $\mathrm{Pb}$ objects have been assumed to originate in the Massif Central, including the artefacts found in Germania ${ }^{87}$. Recently, another assemblage of Roman and Byzantine $\mathrm{Cu}$ and $\mathrm{Cu}$-alloy coins nummi minimi from the fourth to eighth century $\mathrm{AD}$ was found to be consistent with the deposits in the Massif Central, suggesting a long-term mining tradition of local mineral resources ${ }^{88}$. On the other hand, critical notes have also cast some doubt on the Lyon crucibles, pointing out their lack of technical properties ${ }^{6}$. Nevertheless, based on the reasons presented above, we are confident that our data, in fact, indicate the early Roman cementation in the south-eastern part of the Massif Central, and the increasing evidence for the Imperial exploitation of $\mathrm{Cu}, \mathrm{Zn}$ and $\mathrm{Pb}$ in general ${ }^{59,71}$ supports the original interpretation of the Lyon crucibles ${ }^{80,81}$.

The origin of most of the Bohemian brass in the Massif Central, and possibly its fabrication directly in Lyon, is not entirely impossible, as it is in accordance with the recent research, regularly pointing out the Gallic production ${ }^{2,59,71,87}$. The consistency of these deposits with the data from an entirely different cultural tradition may appear surprising at first; however, they only underscore the complexity of the socio-economic networks and the organisation of the metal supplies taking place already in the Early Roman period. Given the presence of the mint in Lugdunum (Lyon), a hypothetical origin of brass for the imperial coinage in the Massif Central appears to be very likely and should be verified by further analyses. The proximity of numerous rich ore deposits to Lugdunum was undoubtedly crucial for its economic importance. These indices could have been underestimated before the publication of chemical data from this area that supported the ancient exploitation of local resources. Furthermore, the consistency of the $\mathrm{Pb}$ isotope compositions with samples from the late Iron Age may indicate a long-distance distribution of these mineral resources as soon as around the middle of the first century BC, i.e. the time directly around Caesar's military campaigns in Gaul.

\section{Conclusions}

The majority of samples from this study were made of high-quality brass, arguably of the Roman origin. The $\mathrm{Pb}$ isotope data show a clear consistency with ore deposits in the Massif Central, especially with Pb-Zn deposits near Les Malines. In addition, a high degree of homogeneity of the analysed samples in terms of their $\mathrm{Pb}$ isotope ratios probably excludes recycling using significantly different resources. Whether the Massif Central connection is provided by $\mathrm{Pb}$ contained in the $\mathrm{Cu}$ source (metallic or geological), or is a result of the cementation process, cannot be unambiguously distinguished. Given the high purity of the Roman $\mathrm{Cu}-$ known from the $\mathrm{Cu}$ ingots and $\mathrm{Cu}$-based coinage - with low $\mathrm{Pb}$ levels compared to slightly $\mathrm{Pb}$-enriched brass samples, a $\mathrm{Pb}$ isotope signal linked to the $\mathrm{Pb}-\mathrm{Zn}$ ores is more likely. Nevertheless, as indicated by non-brass samples from our assemblage and local provenance of the AES coins of the first altar series from Lyon ${ }^{71}$, even $\mathrm{Cu}$ could come from the same territory.

The archaeological cultural groups used to categorise samples appear to have only a moderate significance in the pattern of trace element composition; even the $\mathrm{Pb}$ isotope ratios were not influenced significantly compared to categorisation of the samples according to dating. If we accept the possibility that the $\mathrm{Pb}$ isotope compositions refer to lead originating in the cementation medium, the variation in trace element patterns may point to various $\mathrm{Cu}$ sources, or it may be a result of some further admixtures. Such fact does not contradict a possible different origin of a given artefact suggested by its typological classifications and refers solely to the material used for its fabrication.

An important message provided by the combined chemical and $\mathrm{Pb}$ isotope analysis is the inconsistency of brass artefacts with contemporary brass coinage, the Roman sestertii. However, this finding requires verification by future analysis of a more varied selection of brass coins using the state-of-the-art analytical methods.

The best level of consistency is found among samples with high $\mathrm{Zn}$ content from the phase R B1, i.e. a period around the turn of the Era and the following five decades of the first century AD. Already the artefacts from the late Iron Age do not fall outside the range of $\mathrm{Pb}$ isotope ratios of the Massif Central deposits. Therefore, it can be assumed that the brass production might have started in the Massif Central as early as around the middle of the first century BC. The existence of Gallic brass coins from the time of Caesar's military campaigns in Gaul supports this hypothesis ${ }^{67}$. Also, there is evidence of large-scale exploitation of $\mathrm{Au}$ in the Massif Central that took place already prior to the Roman conquest ${ }^{89,90}$. It is generally accepted that the Romans benefited from the developed tradition of local Gallic mining ${ }^{91}$. The importance of natural resources in the Massif Central for the expanding Roman Empire is underlined by the intensive Fe production around the Montagne Noire area that became significant in the first century AD. According to archaeometric analyses, local Fe was distributed widely via long-distance trade and served as a vital source of material for the Roman army ${ }^{92,93}$. 
The influx of brass to the territories north of the Alps occurred as early as in southern Europe and the Gaul, thus indicating the instant popularity of the new and attractive material. The earliest evidence of brass used in diplomatic contacts with the indigenous populations can be already seen in the late Iron Age. The nature of its distribution mechanisms is hard to evaluate, but in that period, brass was still a rare commodity. Massive-scale and, perhaps more importantly, a regular occurrence is dated no earlier than the Augustan and Tiberian Era. Brass became a ubiquitous yet still highly valued commodity in Germanic society. Its special social status was derived from its distinctive visual qualities and, initially, its exclusive Roman provenance. The level of dependency of the Barbarian society on an external material supply from the Romans appears to be very high. Based on the current scientific evidence, the importance of brass in political relations between the Romans and Barbarians, possibly similar to the role of the silver coins in northern Britain ${ }^{94}$ can be assumed. This material with the connotations of prestige and luxury could serve as an effective medium in determining the quality of relations among different Barbarian groups. The 'value to cost-effectiveness ratio' for the material such as brass seems to have played in the Roman favour. The archaeological evidence from other regions beyond Bohemia suggests that a similar strategy of diplomatic contacts may also apply to other territories where early Roman brass artefacts occur (i.e. Slovakia, Poland, Germany) ${ }^{95}$.

Given the sufficient influx of the Roman brass into the Barbarian territories, the recycling has not affected the geochemical properties attributed to the original Roman aurichalcum as much as is observed for materials from the second century $\mathrm{AD}^{66,96}$. Only the samples from the earliest phase of the Early Roman period (R A) may have had their $\mathrm{Pb}$ isotope ratios influenced by Iberian $\mathrm{Cu}$ sources. A specificity of data from the latest phase $(\mathrm{R}$ B2) could be explained at this point by exploitation of different deposits in the Massif Central than in the early stages of brass production. Such a hypothesis is also supported by the second century AD brass ingots from the shipwreck of Aléria that share the $\mathrm{Pb}$ isotope signature with our samples and is also thought to be produced in the Massif Central. Another explanation brings the recently analysed Zn ores from Northern Italy into consideration as well ${ }^{77}$. Naturally, mixing of various resources in these later stages of Roman brass production is always an important issue for consideration and hopefully will be addressed in future studies on this topic.

The volume of material entering the Germania Magna in the Early Roman period is hard to estimate and represents a research topic on its own. There have been some rough estimations in the work of Becker ${ }^{97}$ for the Barbarian territory of the late Roman Germania, which led to an estimated 2.5 tons of material just for brooches. Given the larger dimensions of the Early Roman brooches compared to Late Roman types, plus the overall abundance of the metallic goods in the Early Roman graves, the quantity of consumed material must have been probably higher than that estimated.

\section{Methods}

Selected artefacts were drilled to the metal core to avoid the corrosion layers and collect the minimum sufficient amount of material for the chemical and $\mathrm{Pb}$ isotope analyses. Due to the small sizes of the artefacts and the high corrosion stage of some, the sample weight varied between 0.01 and $0.05 \mathrm{~g}$. Because of the sample preparation methodology, As contents were not determined.

Samples of drilled-out bronze/brass materials were carefully weighed into pre-cleaned Savillex beakers, dissolved in a mixture of $6 \mathrm{M} \mathrm{HCl}-7 \mathrm{M} \mathrm{HNO}_{3}(3: 1 \mathrm{v} / \mathrm{v})$ with several drops of $23 \mathrm{M} \mathrm{HF}$ and placed on a hotplate for $24 \mathrm{~h}$ at $50{ }^{\circ} \mathrm{C}$. For the measurements of element abundances, freshly prepared solutions were dried down and re-dissolved in $2 \% \mathrm{HNO}_{3}$. The abundances of selected elements were determined using an Agilent 7900x inductively coupled plasma mass spectrometer (ICP-MS), housed at the Czech Geological Survey.

The chemical procedures for $\mathrm{Pb}$ isolation and purification employed two chromatographic columns. The first step was modified from Pin et al. ${ }^{98}$ and used pre-cleaned and pre-conditioned Sr.Spec resin (50-100 mesh; Triskem, France) packed in $0.2 \mathrm{~mL}$ columns. Samples were dried down and re-dissolved in $2 \mathrm{M} \mathrm{HCl}$. Lead was eluted with $6 \mathrm{M} \mathrm{HCl}$. The second step employed anion-exchange resin BioRad AG 1×8 (100-200 mesh) combined with $\mathrm{HCl}$ and $\mathrm{HBr}$ as elution media, following the methodology outlined in Romer et al. ${ }^{99}$. The eluted $\mathrm{Pb}$ fraction was then dried down and repeatedly re-dissolved with $50 \mu \mathrm{l} 14 \mathrm{M} \mathrm{HNO}_{3}$ to remove any residual organic material.

Prior to $\mathrm{Pb}$ isotope measurements, the dried $\mathrm{Pb}$ fractions were re-dissolved in $1 \mathrm{~mL} 2 \% \mathrm{HNO}_{3}$ and doped with $\mathrm{Tl}$ solution (NIST SRM 997; ${ }^{205} \mathrm{Tl} /{ }^{203} \mathrm{Tl}=2.3871$ ). Lead isotope compositions were determined using a Neptune multi-collector ICPMS (ThermoFisher) coupled to an Aridus 2 desolvating unit (Cetac), housed at the Czech Geological Survey, in static mode. Sample analysis followed a conventional standard-sample-standard bracketing protocol in which the SRM-981 reference material solution was run after every unknown sample. Potential ${ }^{204} \mathrm{Hg}$ isobaric interference on ${ }^{204} \mathrm{~Pb}$ was monitored at mass ${ }^{202} \mathrm{Hg}$ and corrected by assuming natural $\mathrm{Hg}$ isotope ratios $\left({ }^{202} \mathrm{Hg} /{ }^{204} \mathrm{Hg}=4.35\right)$. Correction of the measured $\mathrm{Pb}$ isotope ratios for mass discrimination utilised a generalised power law and natural isotope composition of $\mathrm{Tl}^{100}$. The results were then normalised off-line to the certified values for SRM 981, and the combined statistics for three measurements of each unknown sample were calculated. Data represent the uncertainty-weighted mean of three replicate measurements. Repeat measurements of NBS 981 yielded mean ${ }^{206} \mathrm{~Pb} /{ }^{204} \mathrm{~Pb},{ }^{207} \mathrm{~Pb} /{ }^{204} \mathrm{~Pb}$ and ${ }^{208} \mathrm{~Pb} /{ }^{204} \mathrm{~Pb}$ ratios of $16.942 \pm 0.003,15.4998 \pm 0.0030$ and $36.725 \pm 0.007$ (2SEM, $n=66)$, respectively.

Samples dated into the La Tène period and comparative Iron Age samples were processed with a slightly different methodology detailed elsewhere ${ }^{21}$.

For consistency in the data evaluation, the ore deposits data were prepared for the comparative analysis by removing multivariate outliers (i.e. those that would significantly affect the quality of the analysis) detected using the Mahalanobis distance ${ }^{76}$. This step is a prerequisite to fitting linear models to the data or using any other method to visualise the trends. By outliers, we understand data points with extreme values regarding the 
shape of the whole data distribution in a multidimensional setting defined by lead isotopic ratios $\left({ }^{206} \mathrm{~Pb} /{ }^{204} \mathrm{~Pb}\right.$, ${ }^{207} \mathrm{~Pb} /{ }^{204} \mathrm{~Pb},{ }^{208} \mathrm{~Pb} /{ }^{204} \mathrm{~Pb},{ }^{207} \mathrm{~Pb} /{ }^{206} \mathrm{~Pb}$ and ${ }^{208} \mathrm{~Pb} /{ }^{206} \mathrm{~Pb}$, respectively).

Received: 14 July 2021; Accepted: 8 December 2021

Published online: 10 January 2022

\section{References}

1. Craddock, P. T. The composition of the copper alloys used by the Greek, Etruscan and Roman civilizations. J. Archaeol. Sci. 5, (1978).

2. Hanel, N. \& Bode, M. Messingbarren aus einem römischen Schiffswrack bei Aléria (Korsika). in From Bright Ores to Shiny Metals. Festschrift for Andreas Hauptmann on the Occasion of 40 Years Research in Archaeometallury and Archaeometry. Montanhistorische Zeitschrift. Der Anschnitt Beiheft 29. (eds. Körlin, G., Prange, M., Stöllner, Th. \& Yalcin, Ü.) 167-181 (2016).

3. Caley, E. R. Orichalcum and related ancient alloys. (American Numismatic Society, 1964).

4. Craddock, P. T. Zinc in classical Antiquity. in 2000 Years of Zinc and Brass (ed. Craddock, P. T.) 1-6 (1998).

5. Bayley, J. The production of brass in antiquity with particular reference to Roman Britain. in 2000 Years of zinc and brass (ed. Craddock, P. T.) 7-26 (1998)

6. Rehren, T. Small size, large scale. Roman brass production in Germania inferior. J. Archaeol. Sci. 26, 1083-1087 (1999).

7. Craddock, P. T. \& Eckstein, K. Production of brass in antiquity by direct reduction. in Mining and Metal Production Through the Ages (eds. Craddock, P. T. \& Eckstein, K.) 216-230 (Archetype, 2003)

8. Catalli, F. Numismatica greca e romana. (Istituto Poligrafico e Zecca dello Stato, 2003).

9. Istenič, J. \& Šmit, Ž. The beginning of the use of brass in Europe with particular reference to the south-eastern Alpine region. in Metals and Mines: Studies in Archaeometallurgy (eds. la Niece, S., Hook, D. \& Craddock, P. T.) 140-147 (London Archetype Publications / British Museum, 2007).

10. Istenič, J. Roman military equipment and the beginnings of the Roman use of brass in Europe. In Waffen in Aktion Akten 6 International Roman Military Equipment Conference, Xanten Xantener Xanten 13.-16. 6. 2007. Xantener Berichte Berichte 16 (eds Busch, A. W. \& Schalles, H. J.) 237-242 (Maniz, Philipp von Zabern, 2009).

11. di Fazio, M., Felici, A. C., Catalli, F. \& de Vito, C. Microstructure and chemical composition of Roman orichalcum coins emitted after the monetary reform of Augustus (23 B.C.). Sci. Rep. 9, (2019).

12. Danielisová, A. Bohemia at the end of the La Tène period: Objects, materials, chronology, and main development trends - A review. Památky Archeologické 111, 113-157 (2020).

13. Klein, S. \& von Kaenel, H.-M. The early Roman Imperial Aes coinage: metal analysis and numismatic studies. Schweizerische Numismatische Rundschau 79, 53-106 (2000).

14. Klein, S., Lahaye, Y., Brey, G. P. \& von Kaenel, H.-M. The early roman imperial AES coinage II: Tracing the copper sources by analysis of lead and copper isotopes-copper coins of Augustus and Tiberius. Archaeometry 46, (2004).

15. Klein, S. et al. Copper ingots from the western Mediterranean Sea: Chemical characterisation and provenance studies through lead- and copper isotope analyses. J. Roman Archaeol. 20, (2007).

16. Bode, M., Rothenhöfer, P. \& Batanero, D. G. Lost in the south: A Roman copper ingot form the area of Tarragona in the Baetica. Revista Onoba 6, 243-248 (2018).

17. Bode, M., Hauptmann, A. \& Mezger, K. Tracing Roman lead sources using lead isotope analyses in conjunction with archaeological and epigraphic evidence-a case study from Augustan/Tiberian Germania. Archaeol. Anthropol. Sci. 1, (2009).

18. Schwab, R. Copper Alloys and Non-ferrous Metalworking in the Oppidum of Manching (Germany). in Under the volcano: Proceedings of the International Symposium on the Metallurgy of the European Iron Age (SMEIA) held in Mannheim, Germany, 20-22 April 2010 (eds. Pernicka, E. \& Schwab, R.) 175-188 (Verlag Marie Leidorf GmbH., 2014).

19. Dungworth, D. Roman copper alloys: analysis of artefacts from Northern Britain. J. Archaeol. Sci. 24, (1997).

20. Danielisová, A., Strnad, L. \& Mihaljevič, M. Circulation patterns of copper-based alloys in the late iron age Oppidum of Tŕísov in Central Europe. Metalla 24, 5-18 (2018).

21. Danielisová, A. et al. Claiming the land or protecting the goods? The Duchcov hoard in Bohemia as a proxy for 'Celtic migrations' in Europe in the 4th century BCE. J. Archaeol. Sci. 127, (2021).

22. Salač, V. (ed. ). Prehistory of Bohemia 7. The Roman Iron Age and the Migration Period. (2013).

23. Pitts, L. F. Relations between Rome and the German 'Kings' on the Middle Danube in the First to Fourth Centuries A.D. J. Roman Stud. 79, (1989).

24. Wolters, R. Die Römer in Germanien (Verlag C. H, 2000).

25. Kehne, P. Limitierte Offensiven: Drusus, Tiberius und die Germanienpolitik im Dienste des augusteischen Prinzipats. in Res publica reperta. Zur Verfassung und Gesellschat der römischen Republik und des frühen Prinzipats. Festschrift für Jochen Bleicken zum 75. Geburtstag. (ed. Spielvogel, J.) (Steiner, 2002).

26. Salač, V. \& Bemann, J. (eds. ). Mitteleuropa zur Zeit Marbods.Tagung Roztoky u Křivoklátu 4.-8. 12. 2006. 19. Internationales Symposium Grundprobleme der frühgeschichtlichen Entwicklung im mittleren Donauraum. (2009).

27. Droberjar, E. Poznámky k dějinám a archeologii Marobudovy říše / Bemerkungen zur Geschichte und Archäologie des MarbodReiches. Archeologie ve středních Čechách 12, 575-600 (2008).

28. Frána, J. Metallanalysen der germanischen und römischen Gegenstände aus Dobřichov-Pičhora. in Dobřichov-Pičhora. Ein Gräberfeld der älteren römischen Kaiserzeit in Böhmen (ed. Droberajar, E.) 185-194 (1999).

29. Droberjar, E. \& Frána, J. Antická mosaz (aurichalcum) v českých nálezech časné doby římské / Das römerzeitliche Messing (Aurichalcum) in böhmischen Funden der frühen römischen Kaiserzeit. Archeologie ve středních Čechách 8, 441-462 (2004).

30. Bachmann, H. G. \& Jackenhövel, A. Zu den Stabbarren aus dem Rhein bei Mainz. Archäologisches Korrespondenzblatt 4, 139-144 (1974).

31. Militký, J. Keltské a antické mince z oppida Hradiště u Stradonic v bývalé fürstenberské sbírce na hradě Křivoklát a v Donaueschingen / Celtic and ancient coins from the Hradiště oppidum by Stradonice in the former Fürstenberg collection at the Křivoklát castle and in Donaueschingen. Numismatický sborník 24, 27-64 (2009).

32. Kunow, J. Die römische Import in der Germania Libera bis zu den Markomannenkriege. (1983).

33. Burnett, A., Craddock, P. T. \& Preston, K. New light on the origins of orichalcum. in Proceedings of the 9th International Congress of Numismatics I, Louvain-la-Neuve. Association Internationale des Numismates Professionals 6 (eds. Hackens, T. \& Weiller, R.) vol. 6 263-268 (1982).

34. Droberjar, E. Veteres illic Sueborum praedae et nostris e provinciis lixae ac negotiatores reperti..." (Tacitus, Ann. II,62,3). K interpretaci římských importů u českých Svébů v době Marobudově / Zur Interpretation der römischen Importe bei den böhmischen Sueben in der Marbod-Zeit. in Archeologie barbarů 2006 (eds. Droberjar, E. \& Chvojka, O.) 43-93 (2007).

35. Danielisová, A. et al. Rituals, hoards and travellers? Archaeometry of the iron age bronze wheel amulets. Interdiscip. Archaeol. 11, (2020).

36. Garbsch, J. Die norisch-pannonische Frauentracht. Münchner Beiträge zur Vor- und Frühgeschichte 11. (Beck, 1965). 
37. Cosack, E. Die Fibeln der Älteren Römischen Kaiserzeit in der Germania libera (Dänemark, DDR, BDR, Niederlande, CSSR), Teil 1. (1979).

38. Riha, E. Die römischen Fibeln aus Augst und Kaiseraugst. Forschugen in Augst 3, (1979).

39. Riha, E. Die römischen Fibeln aus Augst und Kaiseraugst. Die Neufunde seit 1975. Fundberichte aus Baden-Württemberg 21, (1996).

40. Völling, Th. Studien zu Fibelformen der jüngeren vorrömischen Eisenzeit und ältesten römischen Kaiserzeit. Bericht der RömischGermanischen Komission 75, 147-282 (1994).

41. Gugl, Ch. Die römischen Fibeln aus Virunum. (1995).

42. Droberjar, E. Časně římské spony západní provenience v Čechách / Frührömische Fibeln der Westprovinzen in Böhmen. Archeologie ve středních Čechách 1, 273-301 (1997).

43. Völling, T. Germanien an der Zeitenwende: Studien zum Kulturwandel beim Übergang von der vorrömischen Eisenzeit zur älteren römischen Kaiserzeit in der Germania Magna. BAR International Ser. 1360, (2005).

44. Droberjar, E. Hornolabští Svébové - Markomani. K problematice dalš́ího vývoje grossromstedtské kultury ve stupni Eggers B1 („Zeitgruppe 3“) v Čechách (dobřichovská skupina) / Oberelbsweben - Markomanen. Zur Problematik der weiteren Entwicklung der Grossromstedt-Kultur in der Stufe Eggers B1 (Zeitgruppe 3) in Böhmen (Dobřichov-Gruppe). Archeologie ve středních Čechách 10, 599-712 (2006).

45. Sedlmayer, H. Die Fibeln vom Magdalensberg. Funde der Grabungsjahre 1948-2002 und Altfunde des 19. Jahrhunderts. in Archäologische Forschungen zu den Grabungen auf dem Magdalensberg vol. 16 (Verlag des Landesmuseums Kärnten, 2009).

46. Droberjar, E. Römische Fibeln aus Gräbern und Siedlungen des 1.-3. Jahrhunderts in Böhmen - eine Übersicht. in Archäologie zwischen Römern und Barbaren. Kolloquien zur Vor- und Frühgeschichte 22/1 (eds. Voß, H.-U. \& Müller-Scheeßel, N.) 495-510 (2016).

47. Kunow, J. Die Hauptserie der Augenfibeln: Gruppe III, Fig. 45 - 54. in 100 Jahre Fibelformen nach Oscar Almgren. Internationale Arbeitstagung 25. - 28. Mai 1997 in Kleinmachnow, Land Brandenburg. Forschungen zur Archäologie im Land Brandenburg 5 (ed. Kunow, J.) 93-118 (1998).

48. Droberjar, E. Dobřichov-Pičhora. Ein Brandgräberfeld der älteren römischen Kaiserzeit in Böhmen (Ein Beitrag zur Kenntnis der Marbod-Reiches). Fontes Archaeologici Pragenses 23, (1999).

49. Kunow, J. Zum Handel mit römischen Importen in der Germania libera. in Untersuchungen zu Handel und Verkehr der vor- und frühgeschichtlichen Zeit in Mittel- und Nordeuropa 1 (ed. Düwel, K.) 430-450 (1985).

50. Lund-Hansen, U. Römischer Import im Norden. Warenaustausch zwischen dem Römischen Reich und dem freien Germanien während der Kaiserzeit unter besonderer Berücksichtigung Nordeuropas. in Nordiske Fortidsminder 10 (1987).

51. Erdrich, M. Rom und die Barbaren. Das Verhältnis zwischen dem Imperium Romanum und den germanischen Stämmen vor seiner Nordwestgrenze von der späten römischen Republik bis zum Gallischen Sonderreich. Römisch-Germanische Forschungen 58, (2001).

52. Bursák, D. Spona typu Almgren 18 ze sbírky J. A. Jíry a další nálezy z Lipan / An Almgren 18 type fibula from J. A. Jíra’s collection and other finds from Lipany (Kolín District, Central Bohemia). Archaeol. Pragensia 24, 154-164 (2020).

53. Demetz, S. Fibeln der Spätlatène- und frühen römischen Kaiserzeit in den Alpenländern. Frühgeschichtliche und provinzialrömische Archäologie. Materialien und Forschungen 4, (1999).

54. Droberjar, E. Od plaňanských pohárủ $\mathrm{k}$ vinařické skupině (kulturní a chronologické vztahy na území Čech v době římské a v časné době stěhování národů) / Von Plaňany-Bechern zur Vinařice-Gruppe (Kulturelle und chronologische Beziehungen in Böhmen in der römischen Kaiserzeit und der Frühvölkerwanderungszeit). Sborník Národního muzea v Praze rada A - Historie 53, 1-58 (1999).

55. Droberjar, E. Plaňanská skupina grossromstedtské kultury. K chronologii germánských nálezůa lokalit v Čechách na sklonku doby laténské a v počátcích doby rrímské / Die Plaňany-Gruppe der Grossromstedter Kultur. Zur Chronologie der germanischen Funde und Fundstellen in Böhmen am Ende der Latènezeit und zu Beginn der römischen Kaiserzeit. in Archeologie barbarů 2005 (eds. Droberjar, E. \& Lutovský, M.) 11-90 (2006).

56. Riederer, J. Ergebnisse der Atomabsorptionsspektralanalyse zur Materialauswahl in der Antike. in Römische und germanische Bunt- und Edelmetallfunde im Vergleich. Archäometallurgische Untersuchungen ausgehend von elbgermanischen Körpergräbern. Bericht der Römisch-germanischen Kommission (eds. Voß, H. U., Hammer, P. \& Lutz, J.) vol. 79 200-203 (1999).

57. Tylecote, R. F., Ghaznavi, H. A. \& Boydell, P. J. Partitioning of trace elements between the ores, fluxes, slags and metal during the smelting of copper. J. Archaeol. Sci. 4, (1977).

58. Pernicka, E. Provenance determination of archaeological metal objects. in Archaeometallurgy in Global Perspective: Methods and Syntheses (eds. Roberts, B. \& Thornton, C.) (Springer Science + Business Media, 2013). doi:https://doi.org/10.1007/978-14614-9017-3_11.

59. Trincherini, P. R., Barbero, P., Quarati, P., Domergue, C. \& Long, L. Where do the lead ingots of the Saintes-Maries-de-la-Mer wreck come from? Archaeology compared with physics. Archaeometry 43, (2001).

60. Artioli, G., Canovaro, C., Nimis, P. \& Angelini, I. LIA of prehistoric metals in the central Mediterranean area: A review. Archaeometry 62, 53-85 (2020).

61. Sinclair, A. J., Macquar, J. C. \& Rouvier, H. Re-evaluation of lead isotopic data, southern Massif Central France. Mineralium Deposita 28, 122-128 (1993).

62. Dungworth, D. Caley's 'zinc decline' reconsidered. Numismatic Chronicle 156, 228-234 (1996)

63. Thornton, C. P. Of brass and bronze in prehistoric Southwest Asia. in Metals and mines: studies in archaeometallurgy (eds. la Niece, S., Hook, D. \& Craddock, P. T.) 123-135 (2007).

64. Orfanou, V. et al. Copper-based metalwork in Roman to early Islamic Jerash (Jordan): Insights into production and recycling through alloy compositions and lead isotopes. J. Archaeol. Sci. Rep. 33, 102519 (2020).

65. Riederer, J. Metallanalysen römischer Sesterzen. Jahrbuch für Numismatik und Geldgeschichte 73-98 (1974).

66. Riederer, J. Metallanalysen römischer Fibeln aus Kempten. in Fiblen und Bronzegeße von Kempten-Cambodunum. Cambodunumforschungen 5. Materialhefte zur Bayerischen Vorgeschichte Reihe A (eds. Schleiermacher, M. \& Flügel, Ch.) 45-52 (1993).

67. Nieto, S. Monnaies arvernes (Vercingétorix, Cas) en orichalque. Revue Numismatique 160, 5-25 (2004).

68. Vadrucci, M. Analysis of Roman imperial coins by combined PIXE, HE-PIXE and $\mu$-XRF. Appl. Radiat. Isot. 143, 35-40 (2019).

69. Höppner, B. et al. Prehistoric copper production in the Inn valley and the earliest copper in central Europe. Archaeometry 47, (2005).

70. Pernicka, E., Lutz, J. \& Stöllner, T. Bronze age copper produced at mitterberg, austria, and its distribution. Archaeol. Austriaca 1, (2016).

71. Klein, S., Kaenel, H.-M. \& Lahaye, Y. The early Roman Imperial aes coinage III: chemical and isotopic characterisation of Augustan copper coins from the mint of Lyons/Lugdunum. Schweizerische numismatische Rundschau 91, 63-110 (2012).

72. Černý, M. Germánské spony starší doby římské v Čechách / Germanic Brooches of the Early Roman Period in Bohemia. (2013).

73. Radivojević, M. et al. The provenance, use, and circulation of metals in the European bronze age: the state of debate. J. Archaeol. Res. 27, 131-185 (2019).

74. Albarede, F. et al. A miner's perspective on $\mathrm{Pb}$ isotope provenances in the Western and Central Mediterranean. J. Archaeol. Sci. 121, 105-494 (2020). 
75. Stos, Z. A. Across the wine dark seas... sailor tinkers and royal cargoes in the Late Bronze Age eastern Mediterranean. in From Mine to Microscope. Advances in the Study of Ancient Technology (ed. Shortland, A.) (2009).

76. Mahalanobis, P. C. On the generalized distance in statistics. Proc. Natl. Inst. Sci. India 2, 49-55 (1936).

77. Merkel, S. W. Calamine of the Bergamasque Alps as a possible source of zinc for Roman brass: Theoretical considerations and preliminary results. Periodico di Mineralogia 90, 247-259 (2021).

78. Boni, M., di Maio, G., Frei, R. \& Villa, I. M. Lead isotopic evidence for a mixed provenance for Roman water pipes from Pompeii. Archaeometry 42, 201-208 (2000).

79. Leblanc, M. Gîtes et gisements de cuivre de la France méridionale: typologie et caractéristiques géochimiques. Archéologie en Languedoc 21, 21-26 (1997).

80. Picon, M., le Nezet-Celestin, M. \& Desbat, A. Un type particulier de grands recipients en terre réfractaire utilizes pour la fabrication du laiton par cementation. in Productions et importations dans le Nord-Ouest de la Gaule et relations avec la Bretagne romaine. Actualité des recherches céramiques, Societé Française d'Etude de la Céramique Antique en Gaule, Actes Congrès Rouen (ed. Rivet, L.) 207-215 (1995).

81. Desbat, A., Meille, E. \& Picon, M. La préparation du laiton par cémentation à l'époque romaine. in Arts du feu et productions artisanales, XXe rencontres Internationales d'Archéologie et d'Histoire d'Antibes (eds. Pétrequin, P., Fluzin, P., Thiriot, J. \& Benoit, P.) $183-188(2000)$

82. La, M. J. fabrication du laiton avant la découverte du procédé Dony d'extraction du zinc. Bulletin Scientifique de l’AEES 36, 1-13 (1938).

83. Werner, O. Analysen mittelalterlicher Bronzen und Messinge II und III. in Archäologie und Naturwissenschaften 2 (eds. Ankner, D., Schauer, P. \& Waurick G.) 106-170 (1981).

84. Bourgarit, D. \& Thomas, N. Ancient brasses: Misconceptions and new insights. in Archaeometallurgy in Europe III: Proceedings of the 3rd International Conference, Deutsches Bergbau-Museum Bochum, June 29 - July 1, 2011. Der Anschnitt Beiheft 26 (eds. Hauptmann, A. \& Modarressi-Tehrani, D.) 255-262 (2015).

85. Domergue, C. Les mines antiques. La production des métaux aux époques grecque et romaine. (2008).

86. Beyrie, A. et al. Une vaste exploitation minière du second Âge du fer. La mine de cuivre des Barrencs (Lastours, FournesCabardès, Aude). Revue archéologique de Narbonnaise 44, 29-46 (2011).

87. Durali-Müller, S., Brey, G. P., Wigg-Wolf, D. \& Lahaye, Y. Roman lead mining in Germany: its origin and development through time deduced from lead isotope provenance studies. J. Archaeol. Sci. 34, 1555-1567 (2007).

88. Birch, T. et al. From nummi minimi to fulūs-small change and wider issues: characterising coinage from Gerasa/Jerash (Late Roman to Umayyad periods). Archaeol. Anthropol. Sci. 11, 5359-5376 (2019).

89. Baron, S. et al. Geochemistry of gold ores mined during celtic times from the North-Western French Massif Central. Sci. Rep. 9, (2019).

90. Cauuet, B. Lor des Celtes du Limousin. (Culture et patrimoine en Limousin, 2004).

91. Domergue, C., Serneels, V., Cauuet, B., Pailler, J.-M. \& Orzechowski, S. Mines et métallurgies en Gaule à la fin de l'âge du Fer et à l'époque romaine. in Celtes et Gaulois : L'Archéologie face à l'histoire, 5: La romanisation et la question de l'héritage celtique: actes de la table ronde de Lausanne, 17-18 juin 2005. Bibracte 12/5. (ed. Paunier, D.) 131-162 (2006).

92. Long, L., Rico, Ch. \& Domergue, C. Les épaves antiques de Camargue et le commerce maritime du fer en Méditerranée nordoccidentale (Ier siècle avant J. C. - Ier après J. C.). L'Africa romana 14, 161-188 (2002).

93. Baron, S. et al. Lingots de plomb et barres de fer des épaves romaines des Saintes-Maries-de-la-Mer (Bouches-du-Rhône, France): Questions de traçabilité comparée. Revue archéologique de Narbonnaise 44, 71-97 (2011).

94. Hunter, F. \& Painter, K. Late Roman Silver. The Traprain Treasure in Context. (2013).

95. Voß, H. U., Hammer, P. \& Lutz, J. Römische und germanische Bunt- und Edelmetallfunde im Vergleich. Archäometallurgische Untersuchungen ausgehend von elbgermanischen Körpergräbern. Bericht der Römisch-germanischen Kommission 79, 107-381 (1998).

96. Vích, D. et al. Soubor kovových předmětů z doby římské z Boršova na Moravskotřebovsku / An Assemblage of Metal Roman Iron Age Artefacts from Boršov in the Moravská Třebová Region. Památky archeologické 111, 159-192 (2020).

97. Becker, M. Verborgener römischer Import. in Das Miteinander, Nebeneinander und Gegeneinander von Kulturen. Zur Archäologie und Geschichtewechselseitiger Beziehungen im 1. Jahrtausend n. Chr. Neue Studien zur Sachsenforschung 2 (eds. Ludowici, B. \& Pöppelmann, H.) 51-56 (2011).

98. Pin, C., Gannoun, A. \& Dupont, A. Rapid, simultaneous separation of $\mathrm{Sr}, \mathrm{Pb}$, and Nd by extraction chromatography prior to isotope ratios determination by TIMS and MC-ICP-MS. J. Anal. At. Spectrom. 29, 1858-1870 (2014).

99. Romer, R. L. et al. Elemental dispersion and stable isotope fractionation during reactive fluid-flow and fluid immiscibility in the Bufa del Diente aureole, NE-Mexico: Evidence from radiographies and Li, B, Sr, Nd, and Pb isotope systematics. Contrib. Miner. Petrol. 149, 400-429 (2005).

100. Košler J., Forst L. \& Sláma J. Lamdate and lamtool: spreadsheet-baserd data reduction for laser ablation ICP-MS. in Laser ablation ICP-MS in the Earth Sciences: current practices and outstanding issues. Short Course Series 40 (ed. Sylvester, P.) 315-317 (Mineralogical Association of Canada, 2008).

\section{Acknowledgements}

This work was supported by the Czech Science Foundation project 18-20096S [Mobility of materials and life cycles of artefacts: archaeometry of metals and glass of the La Tène and Early Roman period]. TM, JM and ZR contributed through the Strategic Research Plan of the Czech Geological Survey (DKRVO/ČGS 2018-2022); The Charles University team (LS, JT) was supported by the institutional funding provided by the Center for Geosphere Dynamics (UNCE/SCI/006).

\section{Author contributions}

A.D. and D.B. designed the research project (Grant 18-20096S). D.B., A.D. and T.M. performed statistical analyses, were responsible for the interpretation of the data, designed the manuscript and the figures. P.P. performed provenance and comparative analyses. T.M., J.M. and Z.R. performed the analyses of Roman period samples. T.M. supervised the data quality. J.T. and L.S. contributed with the measurements of La Tène period samples.

\section{Competing interests}

The authors declare no competing interests.

\section{Additional information}

Supplementary Information The online version contains supplementary material available at https://doi.org/ 10.1038/s41598-021-04044-7. 
Correspondence and requests for materials should be addressed to D.B.

Reprints and permissions information is available at www.nature.com/reprints.

Publisher's note Springer Nature remains neutral with regard to jurisdictional claims in published maps and institutional affiliations.

(c) (i) Open Access This article is licensed under a Creative Commons Attribution 4.0 International cc) License, which permits use, sharing, adaptation, distribution and reproduction in any medium or format, as long as you give appropriate credit to the original author(s) and the source, provide a link to the Creative Commons licence, and indicate if changes were made. The images or other third party material in this article are included in the article's Creative Commons licence, unless indicated otherwise in a credit line to the material. If material is not included in the article's Creative Commons licence and your intended use is not permitted by statutory regulation or exceeds the permitted use, you will need to obtain permission directly from the copyright holder. To view a copy of this licence, visit http://creativecommons.org/licenses/by/4.0/.

(C) The Author(s) 2022 